US Army Corps of Engineers ${ }_{\circledast}$

Engineer Research and

Development Center

Great Lakes Restoration Initiative

\title{
An Evaluation of Soil Phosphorus Storage Capacity (SPSC) at Proposed Wetland Restoration Locations in the Western Lake Erie Basin
}

Jacob F. Berkowitz, Christine M. VanZomeren, Nia R. Hurst,

September 2021 and Kristina J. Sebastian
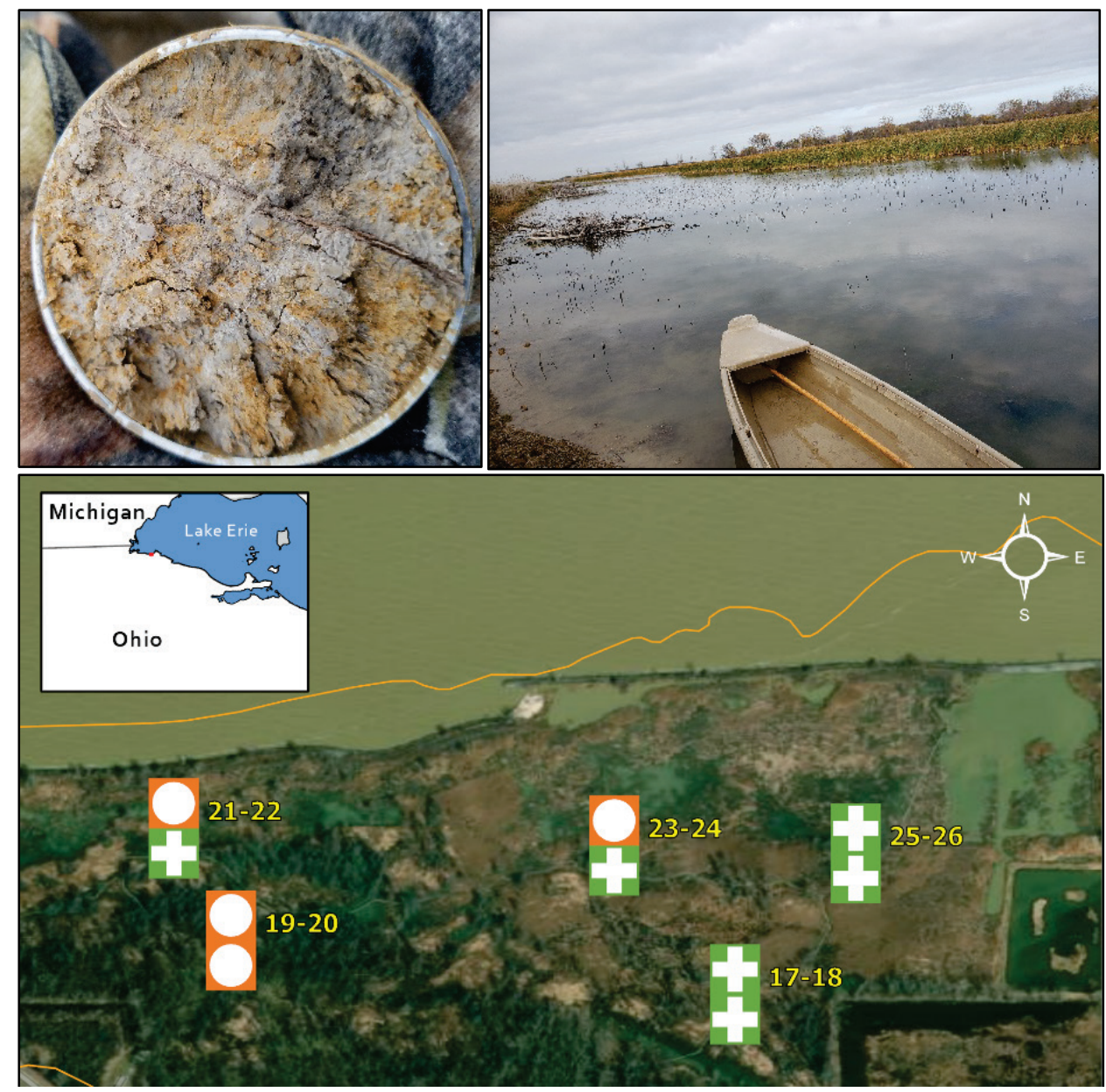
The U.S. Army Engineer Research and Development Center (ERDC) solves the nation's toughest engineering and environmental challenges. ERDC develops innovative solutions in civil and military engineering, geospatial sciences, water resources, and environmental sciences for the Army, the Department of Defense, civilian agencies, and our nation's public good. Find out more at www.erdc.usace.army.mil.

To search for other technical reports published by ERDC, visit the ERDC online library at https://erdclibrary.on.worldcat.org/discovery.

Cover photo credit: Jacob Berkowitz (top). 


\section{An Evaluation of Soil Phosphorus Storage Capacity (SPSC) at Proposed Wetland Restoration Locations in the Western Lake Erie Basin}

Jacob F. Berkowitz, Christine M. VanZomeren, and Nia R. Hurst

Environmental Laboratory

U.S. Army Engineer Research and Development Center

3909 Halls Ferry Road

Vicksburg, MS 39180-6199

Kristina J. Sebastian

UIC Bowhead, LLC

3401 Halls Ferry Road

Vicksburg, MS 39180

Final report

Approved for public release; distribution is unlimited. 


\section{Abstract}

Historical loss of wetlands coupled with excess phosphorus (P) loading at watershed scales have degraded water quality in portions of the western Lake Erie Basin (WLEB). In response, efforts are underway to restore wetlands and decrease $P$ loading to surface waters. Because wetlands have a finite capacity to retain $P$, researchers have developed techniques to determine whether wetlands function as $\mathrm{P}$ sources or sinks. The following technical report evaluates the soil P storage capacity (SPSC) at locations under consideration for wetland restoration in collaboration with the Great Lakes Restoration Initiative (GLRI) and the H2Ohio initiative. Results indicate that the examined soils display a range of $\mathrm{P}$ retention capacities, reflecting historic land-use patterns and management regimes. However, the majority of study locations exhibited some capacity to sequester additional $P$. The analysis supports development of rankings and comparative analyses of areas within a specific land parcel, informing management through design, avoidance, removal, or remediation of potential legacy $P$ sources. Additionally, the approaches described herein support relative comparisons between multiple potential wetland development properties. These results, in conjunction with other data sources, can be used to target, prioritize, justify, and improve decisionmaking for wetland management activities in the WLEB.

DISCLAIMER: The contents of this report are not to be used for advertising, publication, or promotional purposes. Citation of trade names does not constitute an official endorsement or approval of the use of such commercial products. All product names and trademarks cited are the property of their respective owners. The findings of this report are not to be construed as an official Department of the Army position unless so designated by other authorized documents. 


\section{Contents}

Abstract................................................................................................................ ii

Figures and Tables.............................................................................................iv

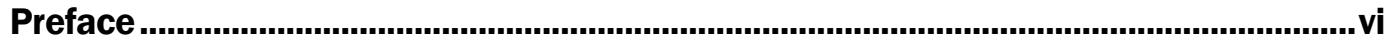

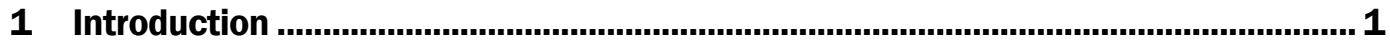

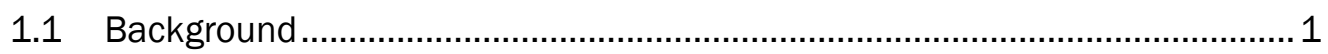

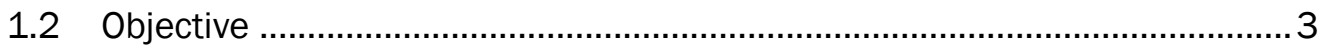

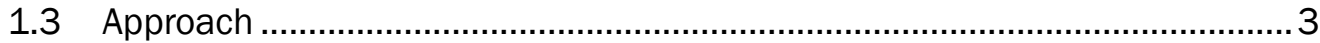

2 Evaluation of Soil P Storage Capacity (SPSC) in Maumee River Watershed for Wetland Best Management Practices (BMP) Development in Support of the Great Lakes Restoration Initiative (GLRI) .................................................. 5

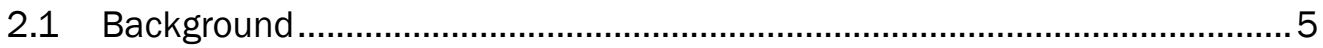

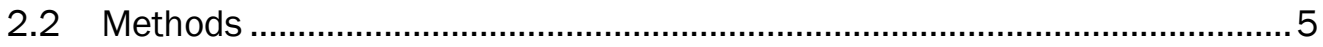

2.3 Results and discussion ................................................................... 8

2.3.1 Soil P storage dynamics.......................................................................................... 8

2.3.2 Prioritizing candidate parcels for wetland BMP development.............................. 12

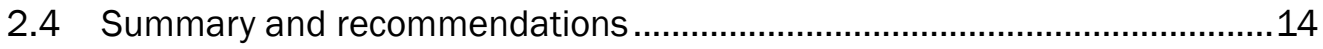

2.4.1 Prioritizing candidate parcels for wetland BMP development................................ 16

3 Evaluation of SPSC for Wetland BMP Development in Support of the H20hio Initiative................................................................................................... 17

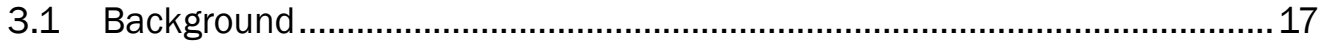

3.2 Methods ............................................................................................... 17

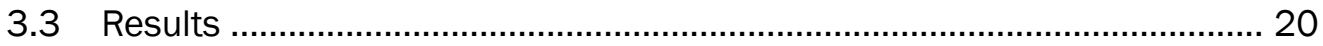

3.4 Summary and recommendations .................................................... 32

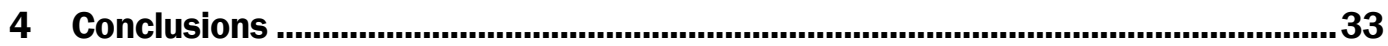

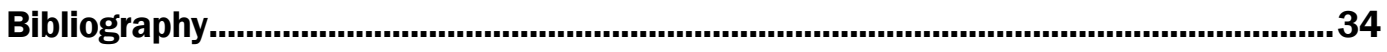

Appendix A: Soil Series and Geologic Data ..................................................................38

Appendix B: Study Location Land Use ...........................................................41

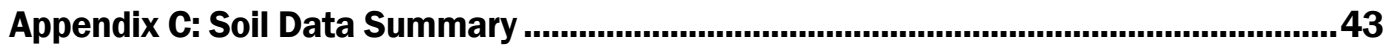

Appendix D: Soil Series Descriptions .......................................................................... 47

Report Documentation Page 


\section{Figures and Tables}

\section{Figures}

Figure 1. Algal bloom in Lake Erie in 2011 (Michalaka et al. 2013, 2). Note the location of the Maumee River in the southwestern corner of the Lake Erie Basin. Michigan lies to the west, and Ohio lies to the south. The Canadian province of Ontario lies to the north.

Figure 2. Maumee watershed, with site locations identified by number. $(1$ mile $=$ 1609.34 meters)

Figure 3. Comparison of mean soil parameters in surface and subsurface soils. Note that surface soils exhibited higher water-soluble phosphorus (WSP) and $\mathrm{P}$ saturation ratios (PSR) while displaying lower soil P storage capacity (SPSC) (denoted here as capacity factor). Error bars represent one standard error of the mean.

Figure 4. Relationship between WSP and SPSC (denoted as capacity factor). Note that WSP generally remains low at SPSC $>0.0$ (orange triangles) and increases below SPSC $=0.0$ (green circles). This relationship suggests that more $P$ may be available for off-site transport when SPSC is reduced, and additional P will likely be retained in soils with higher SPSC values. Two high WSP outliers (12.62 and $130.06 \mathrm{mg} P / \mathrm{L}$ ) were removed to improve the figure scale.

Figure 5. Relationship between soil series and soil-P dynamics (WSP and SPSC values). Note that, although there is considerable variability in the data, the majority of common soil series in the region displayed some capacity to retain additional P. However, P sorption dynamics vary according to site conditions and land-use history.

Figure 6. SPSC in surface and subsurface soils at sample location numbers 37 , $52,36,30$, and 21 . The green plus signs represent SPSC values $>2$ mgPkg $^{-1}$, the yellow triangles represent SPSC between 2 and $0 \mathrm{mgPkg}^{-1}$, and the orange circles represents $<0.0 \mathrm{mgPkg}^{-1}$.

Figure 7. H2Ohio sample locations in northern Ohio. (1 mile = 1609.34 meters)

Figure 8. Relationship between WSP and PSR ${ }_{\mathrm{M} 3}$ used to identify the critical threshold value of 0.01, above which increases in WSP are observed (left panel). Relationship between SPSC and WSP also followed expected patterns, as WSP increased when SPSC was below zero (right panel).

Figure 9. Standing Rush site conditions, sample locations, soil map units, and SPSC. The green plus sign represents SPSC values $>2 \mathrm{mgPkg}^{-1}$, the yellow triangles represent SPSC between 2.0 and $0.0 \mathrm{mgPkg}^{-1}$, and the orange circles represent $<0.0 \mathrm{mgPkg}^{-1}$ in surface and subsurface samples.

Figure 10. Maumee Bay State Park site conditions, sample locations, soil map units, and SPSC. The green plus sign represents SPSC values $>2 \mathrm{mgPkg}^{-1}$, and the orange circles represent $<0.0 \mathrm{mgPkg}^{-1}$ in surface and subsurface samples

Figure 11. Ottawa National Wildlife Refuge site conditions, sample locations, soil map units, and SPSC. The green plus signs represent SPSC values $>2 \mathrm{mgPkg}^{-1}$, and the orange circle represents $<0.0 \mathrm{mgPkg}^{-1}$ in surface and subsurface samples. 
Figure 12. Redhorse Bend site conditions, sample locations, soil map units, and SPSC. The orange circles represent $<0.0 \mathrm{mgPkg}^{-1}$ in surface and subsurface samples.

Figure 13. Fruth Outdoor Center site conditions, sample locations, soil map units, and SPSC. The green plus signs represent SPSC values $>2$ mgPkg $^{-1}$, the yellow triangle represents SPSC between 2.0 and $0.0 \mathrm{mgPkg}^{-1}$, and the orange circles represent $<0.0 \mathrm{mgPkg}^{-1}$ in surface and subsurface samples.

Figure 14. Hecks Bridge site conditions, sample locations, soil map units, and SPSC. The green plus signs represent SPSC values $>2$ mgPkg$^{-1}$ in surface and subsurface samples.

Figure 15. Wolf Creek site conditions, sample locations, soil map units, and SPSC. The green plus sign represents SPSC values $>2 \mathrm{mgPkg}^{-1}$, the yellow triangles represent SPSC between 2.0 and $0.0 \mathrm{mgPkg}^{-1}$, and the orange circle represents $<0.0 \mathrm{mgPkg}^{-1}$ in surface and subsurface samples.

Figure 16. Oakwoods Nature Preserve site conditions, sample locations, soil map units, and SPSC. The green plus signs represent SPSC values $>2 \mathrm{mgPkg}^{-1}$, and the orange circles represent $<0.0 \mathrm{mgPkg}^{-1}$ in surface and subsurface samples.

\section{Tables}

Table 1. Summary of SPSC (mgkg-1) values at each study location. (SE = standard error).

Table 2. Mean SPSC values ( $\mathrm{mgkg}^{-1}$ ) within each land use observed in the study. (SE $=$ standard error; $n=$ number of samples. . 


\section{Preface}

This study was conducted for the USACE Buffalo District under MIPR W81EU602896379 under Project 478112-U4375451, "Great Lakes Restoration Initiative," a non-point source technical support project administered through the Environmental Protection Agency and the United States Army Corps of Engineers (USACE) Buffalo District. The program administer was Mr. Anthony Friona of USACE Buffalo District.

The work was performed by the Wetlands and Coastal Ecology Branch, (Ms. Patricia M. Tolley, Chief) of the US Army Engineer Research and Development Center (ERDC), Environmental Laboratory (EL). At the time of publication, Mr. Mark Farr was Chief of the Ecosystem Evaluation and Engineering Division of EL, and Dr. Jennifer Seiter-Moser was the EL Technical Director for Civil Works. The Deputy Director of EL was Dr. Brandon Lafferty, and the Director was Dr. Edmond J. Russo.

The authors would like to thank the following individuals and organizations who assisted with accessing study locations: Derek Schlea (LimnoTech), Janice Kerns, Scudder Mackey, Christina Kuchle, Laura Jones, Andrew Thompson (Ohio Department of Natural Resources), Eric Kraus (Standing Rush), Jason Lewis (US Fish and Wildlife Service), Sarah Betts (Seneca County Parks), Adam Saylor (Sandusky County Parks), and staff from the cities of Saint Mary and Defiance, Ohio.

The Commander of ERDC was COL Teresa A. Schlosser and the Director was Dr. David W. Pittman.

Portions of this report have been modified and reprinted with permission from Jacob $F$. Berkowitz, Derek A. Schlea, Christine M. VanZomeren and Chelsie M.W. Boles, 2020, "Coupling Watershed Modeling, Public Engagement, and Soil Analysis Improves Decision Making for Targeting P Retention Wetland Locations," Journal of Great Lakes Research 46, no. 5 (October): 1331-1339, https://doi.org/10.1016/j.jglr.2020.06.016. Public Domain. 


\section{Introduction}

\subsection{Background}

Established in 2010, the Great Lakes Restoration Initiative (GLRI) works to protect and restore the largest system of fresh surface water in the world. To that end, the initiative seeks to address nonpoint source phosphorus $(\mathrm{P})^{*}$ pollution, which has been linked with degraded water quality in the Great Lakes (United States Environmental Protection Agency 2020; Baker et al. 2017; Maccoux et al. 2016). More recently, the $\mathrm{H} 2 \mathrm{Ohio}$ initiative was established to reduce excess $\mathrm{P}$ loading to surface waters, restore and create wetlands, and undertake other actions to improve water quality in Ohio and Lake Erie. These two efforts represent innovative regional approaches to nutrient and natural resource management (United States Environmental Protection Agency 2020).

Both the GLRI and H2Ohio initiatives place particular emphasis on reducing $\mathrm{P}$ loading into the western Lake Erie Basin (WLEB), where poor water quality and repeated harmful algal bloom events negatively affect fisheries and waterfowl habitat, access to clean drinking water, recreation, and local economies (Figure 1). Within the region, excess $\mathrm{P}$ from agricultural, urban, and suburban areas induces eutrophication and degrades water quality. A variety of best management practices (BMPs) have been implemented on farms, at the edges of fields, and in urban and suburban areas to decrease nutrient runoff (Sharpley et al. 2006). However, excess nutrients persist and may be exacerbated by projected future climate conditions, requiring additional strategies to improve water quality in the western Lake Erie Basin and throughout the Great Lakes (Bosch et al. 2014). The restoration and creation of wetlands are rapidly emerging as a novel BMP designed to further reduce $\mathrm{P}$ export from target watersheds including those located in the Great Lakes region, while also providing benefits to the habitat, decreasing flood risk, improving water

*. For a full list of the spelled-out forms of the chemical elements used in this document, please refer to US Government Publishing Office Style Manual, 31st ed. (Washington, DC: US Government Publishing Office, 2016), 265, https://www.govinfo.gov/content/pkg/GPO-STYLEMANUAL2016/pdf/GPO-STYLEMANUAL-2016.pdf. 
quality, and providing opportunities for recreation and education (VanZomeren et al. 2019).

Constructed and restored wetlands have previously been used to capture particulate and dissolved $P$ prior to surface water export in a variety of settings, including as engineered treatment wetlands, although they remain less common than other agricultural BMPs (for example, reduced tillage or grassed buffer strips) (Berkowitz et al. 2020). Wetlands reduce $P$ through biotic (for example, vegetation) and abiotic (for example, particulate capture) processes. Long-term $P$ retention is mediated by abiotic soil-P chemical interactions, in which $\mathrm{P}$ is retained by sorption onto clay particles, iron ( $\mathrm{Fe}$ ) and aluminum ( $\mathrm{Al}$ ) oxides and hydroxides, or soil organic materials (Kleinman et al. 2015). However, the long-term $P$ retention capacity of soils is limited by the quantity and availability of sorption sites. If the available $P$ storage capacity of a soil is surpassed, the soil can be converted from a $P$ sink to either a flow-through system, in which $\mathrm{P}$ is neither sequestered nor lost, or a potential $\mathrm{P}$ source, in which $\mathrm{P}$ is exported from the system (VanZomeren et al. 2019).

The accumulation of high $\mathrm{P}$ concentrations in soils has been described as legacy $P$, in which long-term nutrient loading surpasses the capacity of a soil to retain additional $\mathrm{P}$, and soil-bound $\mathrm{P}$ may become available for export to surface waters over time (Sharpley et al. 2013). The establishment and persistence of legacy $\mathrm{P}$ conditions can result in unintended P release and decrease or mute the effects of other nutrientreduction BMPs. Therefore, understanding and quantifying the abundance and status of soil $\mathrm{P}$ sorption sites is essential when considering the development of wetlands as nutrient-reduction BMPs. In response, the following report evaluates soil P storage capacity (SPSC) at select locations in the western Lake Erie Basin. 
Figure 1. Algal bloom in Lake Erie in 2011 (Michalaka et al. 2013, 2). Note the location of the Maumee River in the southwestern corner of the Lake Erie Basin. Michigan lies to the west, and Ohio lies to the south. The Canadian province of Ontario lies to the north.

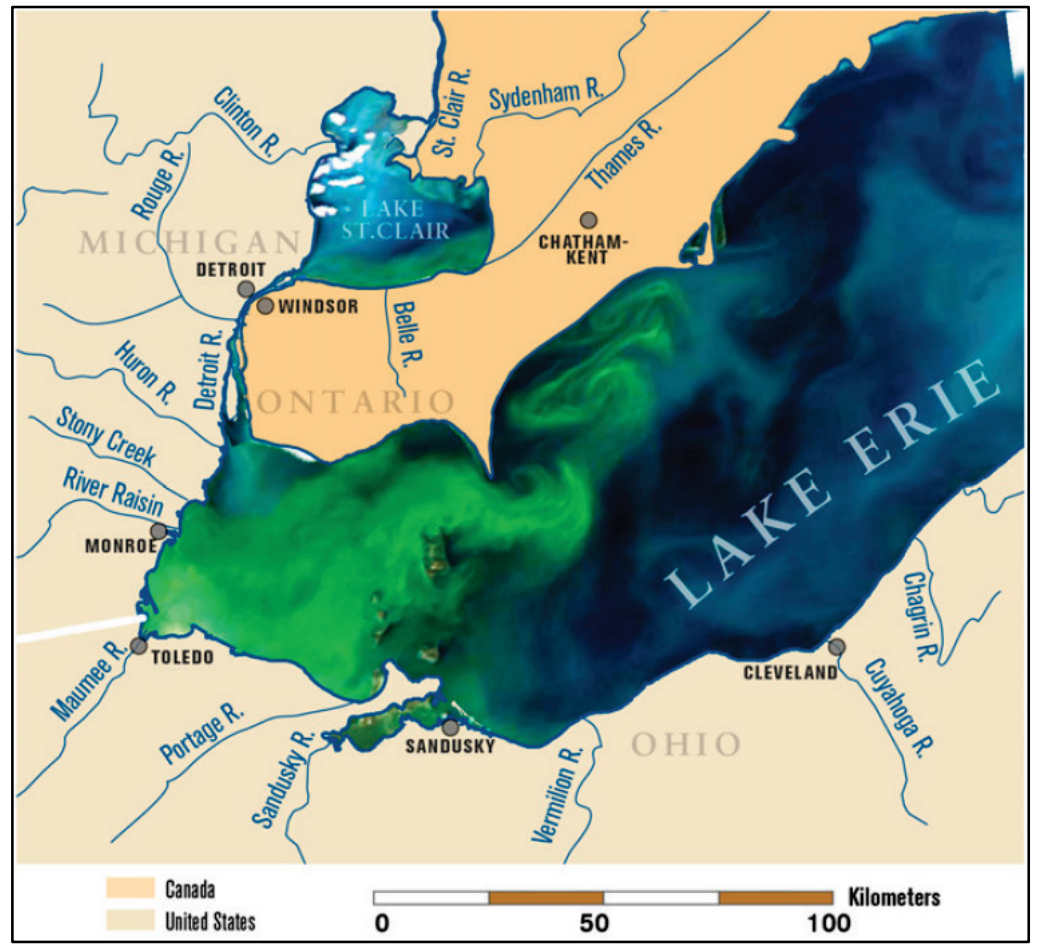

\subsection{Objective}

The following report documents soil characteristics, including SPSC, at select locations in northwestern Ohio. This region is a critical area of concern for nutrient reduction to western Lake Erie, and the construction or restoration of wetlands can serve as a potential BMP to reduce $\mathrm{P}$ input to surface waters. However, additional research is required to evaluate soil-P interactions under BMP scenarios to avoid unintentional P release and identify candidate parcels for wetland BMP development. In response, this study investigated soil-P dynamics at multiple locations under consideration for wetland BMP implementation. The following data can help identify areas capable of retaining additional $\mathrm{P}$, screen candidate parcels for soil $\mathrm{P}$ storage capacity, and provide a template to guide wetland restoration planning activities at local and regional scales.

\subsection{Approach}

This study reports SPSC data across multiple soil types in several northeast Ohio watersheds for the purpose of identifying potential locations for wetland BMP placement. Specifically, this report applies the 
findings of two case studies to describe (1) background information on soil properties that relate to SPSC, (2) methods for determining SPSC, (3) data from case studies evaluating SPSC conducted in support of the GLRI (section 2) and H2Ohio initiatives (section 3), and (4) knowledge gaps and opportunities for additional research. 


\section{Evaluation of Soil P Storage Capacity (SPSC) in Maumee River Watershed for Wetland Best Management Practices (BMP) Development in Support of the Great Lakes Restoration Initiative (GLRI)}

\subsection{Background}

The Maumee River watershed is a highly agricultural watershed of over $16,300 \mathrm{~km}^{2}$ that drains into the WLEB. ${ }^{*}$ As a GLRI priority area, the Maumee River watershed is the focus of several modeling efforts to address P loading into the WLEB (Scavia et al. 2017; Bosch et al. 2011). The Maumee River watershed is the largest $P$ exporter to the WLEB, averaging 2,617 metric tons of $P$ per year (Maccoux et al. 2016). Long-term trend analysis shows loads of both total P (TP) and dissolved reactive $\mathrm{P}$ (DRP) are increasing relative to levels measured in the 1990s, resulting in renewed efforts to reduce $\mathrm{P}$ inputs through additional BMP development, including wetlands designed for $P$ retention (Stow, et al. 2015). In response, a screening effort was conducted to evaluate the SPSC at multiple candidate parcels in the watershed under consideration for wetland BMP implementation.

\subsection{Methods}

A collaborative effort between the US Army Corps of Engineers-Buffalo District, the US Army Engineer Research and Development Center (ERDC), and LimnoTech identified candidate parcels for wetland BMP development through a combination of soil and water assessment tool (SWAT) modeling approaches, geospatial analysis, and soil-map unit interpretation. Berkowitz, et al. (2020) provide details on the site selection and ranking approach. The analysis identified five potential wetland BMP development sites for evaluation of SPSC. The selected parcels were within the St. Marys River and Auglaize River watersheds, sub watersheds located

*. For a full list of the spelled-out forms of the units of measure used in this document, please refer to US Government Publishing Office Style Manual, 31st ed. (Washington, DC: US Government Publishing Office, 2016), 248-52, https://www.govinfo.gov/content/pkg/GPO-STYLEMANUAL-2016/pdf/GPOSTYLEMANUAL-2016.pdf. 
in the southwest part of the Maumee River watershed (Figure 2) (appendix A).

Figure 2. Maumee watershed, with site locations identified by number. $(1 \mathrm{mile}=$ 1609.34 meters)*

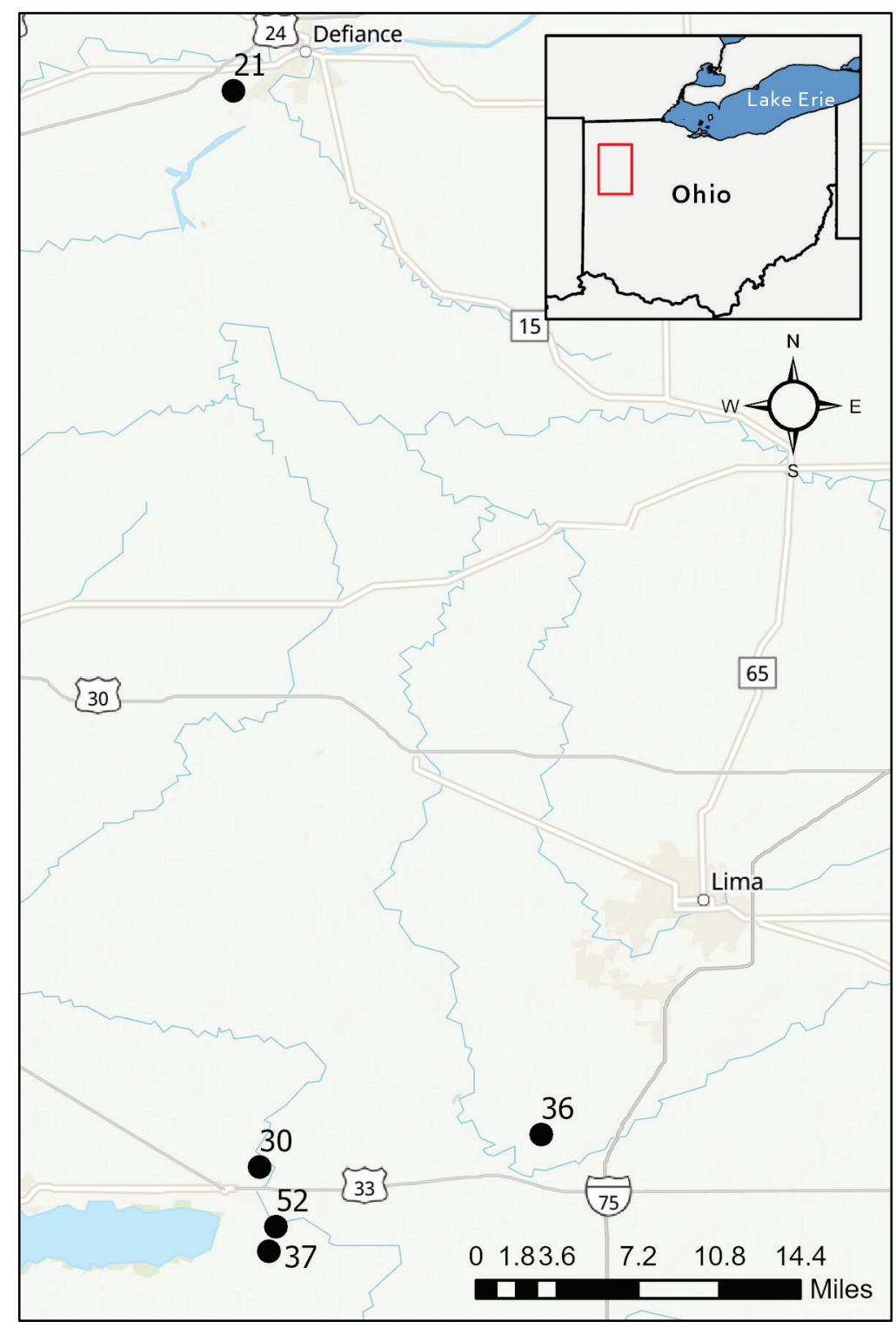

Fifty-two soil samples were collected 6-8 August 2018 for analysis at the five candidate parcels. At each sample location, the top $0-5 \mathrm{~cm}$ of the surface soil was collected. A subsurface soil sample was also collected

*. For a full list of the unit conversions used in this document, please refer to US Government Publishing Office Style Manual, 31st ed. (Washington, DC: US Government Publishing Office, 2016), 345-7, https://www.govinfo.gov/content /pkg/GPO-STYLEMANUAL-2016/pdf/GPO-STYLEMANUAL-2016.pdf. 
below the interface of the A/B or E/B horizons. This approach allowed for analysis of surface conditions within the zone of highest soil $\mathrm{P}$ (Baker et al. 2017) and subsoil conditions to inform subsequent P-optimal wetland project design. A P-optimal literature review was utilized to ensure the best analytical practices (Currie et al. 2017).

Soil samples were homogenized, dried at $30^{\circ} \mathrm{C}$, and ground for watersoluble phosphorus (WSP) and Mehlich 1 extractions. WSP was determined by deionized water extraction for $1 \mathrm{~h}$ followed by filtration through a $0.45 \mu \mathrm{m}$ membrane filter (Kuo 1996; Richardson and Reddy 2013). WSP was analyzed using a SEAL AQ2 Discrete Analyzer (SEAL Analytical, West Sussex, England; EPA-145-A Rev. 1). Method detection limits were $0.005 \mathrm{mgPL}^{-1}$ for WSP. Mehlich 1-extractable $\mathrm{P}, \mathrm{Fe}$, and $\mathrm{Al}$ were determined by Mehlich 1 soil solution (0.0125 $\mathrm{mol} \mathrm{L}^{-1} \mathrm{H}_{2} \mathrm{SO}_{4}$ and $0.05 \mathrm{~mol} \mathrm{~L}^{-1} \mathrm{HCl}$ ) extraction for five minutes followed by filtration through a Whatman No. 42 filter (Reddy et al. 2013; Mehlich 1984). Mehlich 1-extractable P, Fe, and Al were analyzed using a Seal AQ2 Automated Discrete Analyzer (SEAL Analytical, West Sussex, England; AGR-201-A Rev. 1, EPA-149-A Rev. 1, UKAS-509-A, respectively). Method detection limits were $0.015 \mathrm{mgPL}^{-1}$, $0.02 \mathrm{mg} \mathrm{Fe} \mathrm{L}^{-1}$, and $0.01 \mathrm{mg} \mathrm{Al} \mathrm{L}^{-1}$.

The SPSC and P saturation ratio (PSR) were determined using the following formulas (Nair et al. 2011), where the threshold PSRM1 of 0.10 was used according to Nair et al. (2004) and Dari et al. (2018):

$$
\operatorname{SPSC}\left(\mathrm{mg} \mathrm{kg}^{-1}\right)=\left(\text { Threshold PSR }{ }_{M 1}-\text { Soil PSR }_{M 1}\right)\left(\frac{[\text { Mehlich } 1 \mathrm{Fe}]}{56}+\frac{[\text { Mehlich } 1 \mathrm{Al}]}{27}\right) 31 \text {, }
$$

where the PSR is calculated as the molar ratio of Mehlich 1-extractable $\mathrm{P}$ to Mehlich 1-extractable Fe and Al:

$$
\operatorname{PSR}_{M 1}=\frac{\left(\frac{[\text { Mehlich } 1 \mathrm{P}]}{31}\right)}{\left(\frac{[\text { Mehlich } 1 \mathrm{Fe}]}{56}+\frac{[\text { Mehlich } 1 \mathrm{Al}]}{27}\right)} .
$$

Statistical analysis applied Analysis of Variance (ANOVA) where assumptions of normality (Shapiro and Wilk 1965) and homogeneity of variance (Oklin 1960) were met. Data were square-root or log transformed as needed to meet model assumptions. Post hoc testing used the Tukey 
test. The nonparametric Kruskal-Wallis test evaluated differences between factors when data failed to meet model assumptions (Dunn 1964). All statistics were evaluated using SPSS version 20.0 (IBM).

\subsection{Results and discussion}

\subsubsection{Soil P storage dynamics}

Soil sampling locations within each potential constructed wetland location were selected according to the dominant soil series. Soils map units included the Roselms, Paulding, Saranac, Blount, Del Ray, Pewamo, and Shoals series (Table A-1). Drainage classes for these soils ranged from somewhat poorly drained to very poorly drained. Basic hydric descriptions were completed at each sample location according to the guidance provided in Vasilas and Berkowitz (2016) and US Army Corps of Engineers (2010). The soils examined met one or more field indicators of hydric soils, except for sample location \#37 and two sites within sample area \#52, where extensive plowing or soil disturbance and fill material were observed, and hydric soil indicators were absent. Commonly observed hydric soils indicators included F3-Depleted Matrix, F6-Redox Dark Surface, and A11-Depleted Below Dark Surface. Notably, the current wetland status of the parcels was not evaluated, and some sample locations may lack wetland hydrology or hydrophytic vegetation because of historical and ongoing agricultural activities (for example, drainage, plowing) (Vasilas, Hurt, and Berkowitz 2018).

Examining the soil data, WSP (a relative measure of potential $\mathrm{P}$ release) was higher in the surface soils (mean \pm standard error $=8.9 \pm 5 \mathrm{mgPL}^{-1}$ ) than in the subsurface soils $\left(1.4 \pm 0.3 \mathrm{mgPL}^{-1}, p<0.001\right.$, Figure 3$)$. The full soil analysis data set is available in appendix C. Although slightly higher in some locations, these WSP values are similar to reported values in upland soils under plant and animal production systems, where WSP ranged from 0.2 to $5.0 \mathrm{mgPL}^{-1}$ (Dari et al. 2018). Two locations had exceptionally high WSP in the surface soil $\left(13 \mathrm{mgPL}^{-1}\right.$ and $130 \mathrm{mgPL}^{-1}$, sample sites \#52-4 and \#36-5, respectively). Higher WSP values indicate more $\mathrm{P}$ is available to desorb from surface soils and become a potential source of $\mathrm{P}$ to downstream waters. As a result, data suggest that the surface soils contain more $\mathrm{P}$ on soil-exchange sites than subsoils and are more likely to represent a potential $P$ source. The vertical stratification of soil $\mathrm{P}$ within the upper $5 \mathrm{~cm}$ has been previously reported in the 
midwestern United States (Baker et al. 2017), and the accumulation of surface soil $\mathrm{P}$ was not unexpected.

Figure 3. Comparison of mean soil parameters in surface and subsurface soils. Note that surface soils exhibited higher water-soluble phosphorus (WSP) and $\mathrm{P}$ saturation ratios (PSR) while displaying lower soil P storage capacity (SPSC) (denoted here as capacity factor). Error bars represent one standard error of the mean.
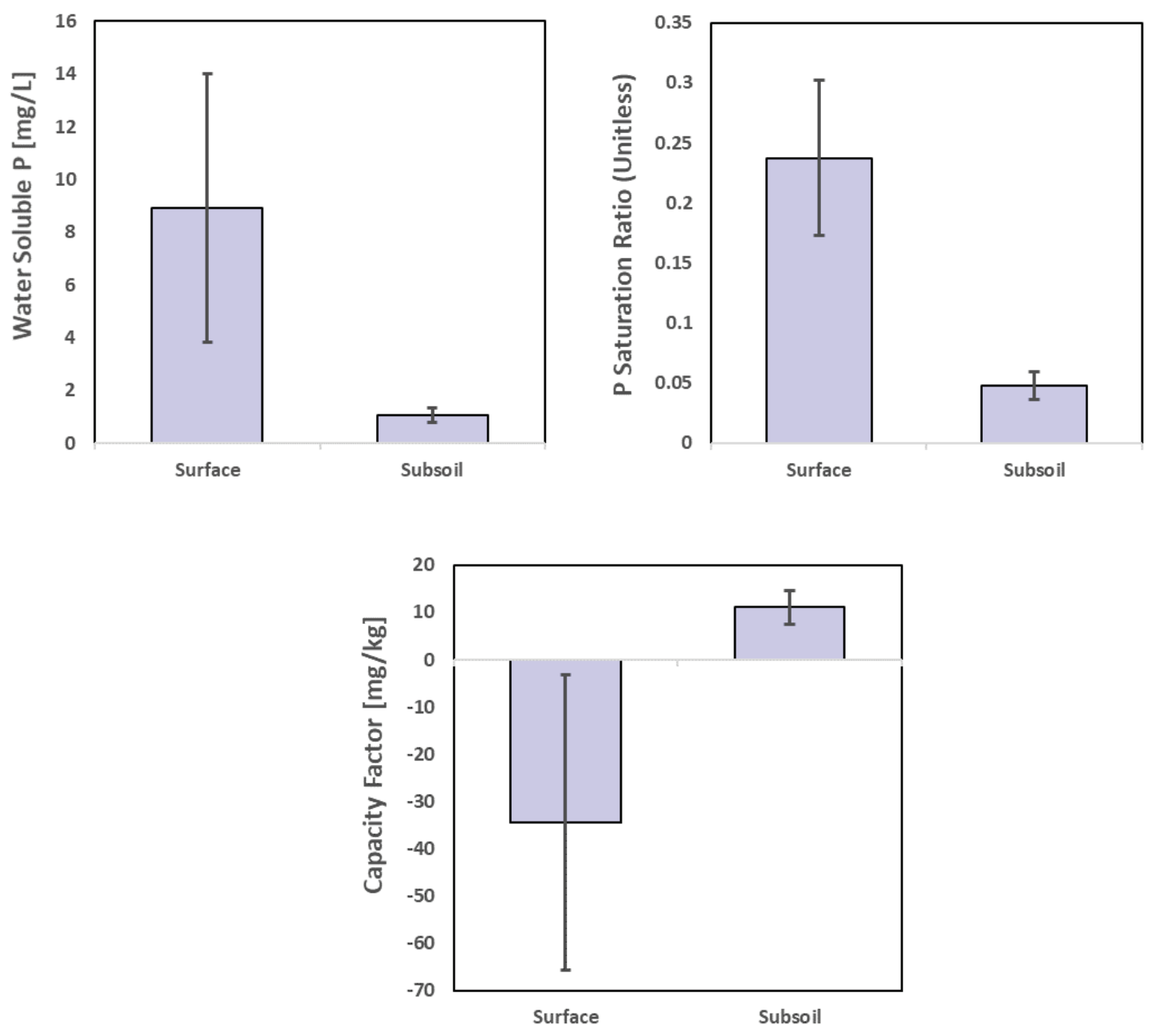

The PSR varied from 0.006 to 0.766 in the surface soil $(0.23 \pm 0.06)$ and 0.003 to 0.288 in the subsurface (0.046 \pm 0.01$)$. Phosphorus sorption ratio values were higher in subsurface soils than in surface horizons $(p<$ o.001), suggesting subsoils have more available $\mathrm{P}$ sorption sites than surface soils. These PSR values are similar to reported values in Dari et al. (2018) except for one soil in sample area \#36 that had an elevated PSR of 1.5. Capacity factors also differed between sample depths, with surface soils displaying more negative SPSC values $\left(-34 \pm 31 \mathrm{mgPkg}^{-1}\right)$ than subsurface results $\left(11 \pm 3.6 \mathrm{mgPkg}^{-1} ; p<0.001\right)$. Higher PSR and lower 
SPSC values in surface soils provide further evidence of vertical stratification of accumulated $P$ at the surface (Baker et al. 2017), suggesting some surface soil removal or remediation may be warranted during P-optimal wetland project design and implementation to increase soil $\mathrm{P}$ retention capacity.

A PSR of 0.1 has been identified as a critical threshold to differentiate between potential P sinks and P sources (Nair et al. 2004). Within the current data set, soils with PSRs $>0.1$ displayed higher WSP on average $\left(12 \pm 7.3 \mathrm{mgPL}^{-1}\right)$ than samples with PSRs $<0.1\left(1.2 \pm 0.3 \mathrm{mgPL}^{-1} ; p<\right.$ o.001). The critical threshold PSR also differed between SPSCs, with PSRs $<0.1$ displaying higher sorption capacity $\left(15 \pm 3 \mathrm{mgPkg}^{-1}\right)$ than soils with PSRs > 0.1 ( $\left.-64 \pm 44 \mathrm{mgPkg}^{-1} ; p<0.001\right)$, which had lower sorption capacities. As reported in other studies, WSP was also closely related to SPSC, where WSP increased when SPSC was below zero (figure 4) (Dari et al. 2018; Nair et al. 2004). These findings provide further evidence that accounting for SPSC remains a critical factor when evaluating potential Poptimal wetland project locations. 
Figure 4. Relationship between WSP and SPSC (denoted as capacity factor). Note that WSP generally remains low at SPSC $>0.0$ (orange triangles) and increases below $S P S C=0.0$ (green circles). This relationship suggests that more $P$ may be available for off-site transport when SPSC is reduced, and additional $P$ will likely be retained in soils with higher SPSC values. Two high WSP outliers (12.62 and $130.06 \mathrm{mg} \mathrm{P} / \mathrm{L}$ ) were removed to improve the figure scale.

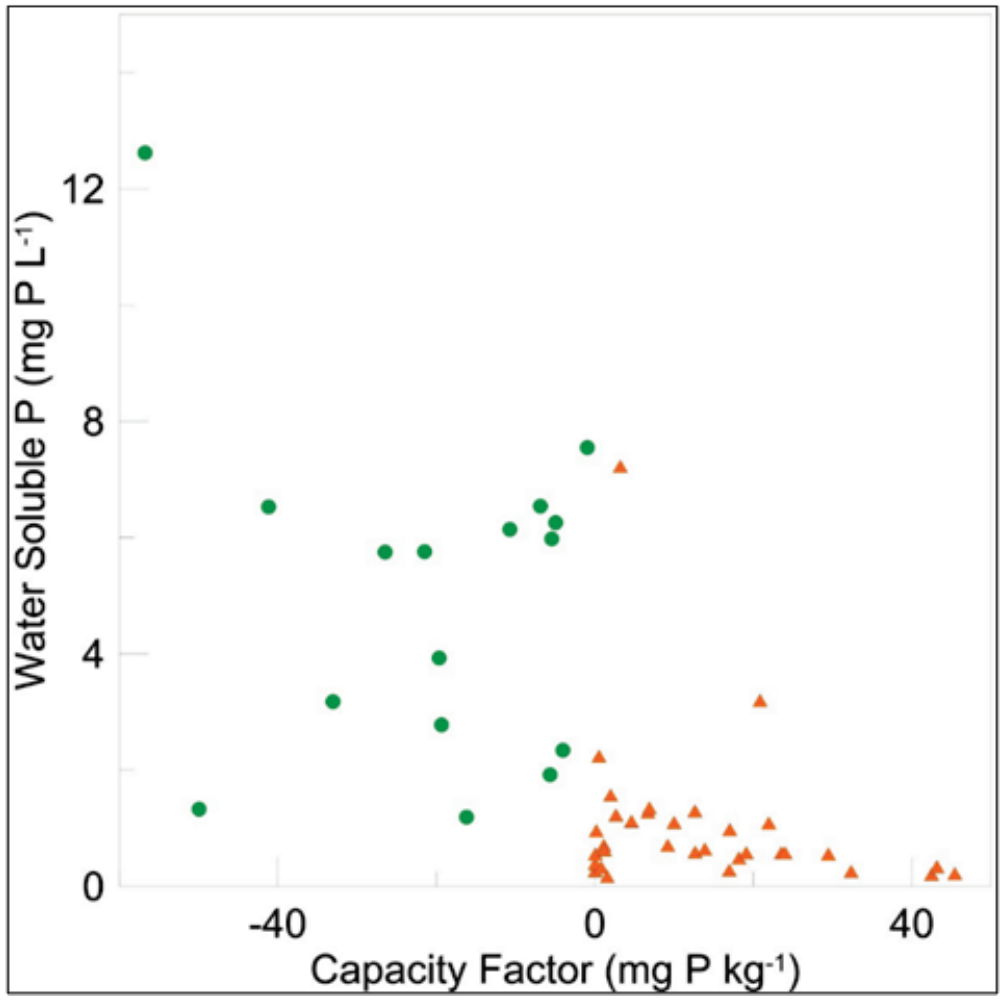

An analysis of soil series data was conducted to evaluate the potential to utilize soil map units to predict soil P storage dynamics. Soil series and geological history can be found in appendix A and soil series descriptions in appendix D. Land use for each sample is located in Table B-1. Examining the extractable $\mathrm{Fe}$ and $\mathrm{Al}$ data, no clear pattern differentiates soil $\mathrm{P}$ sorption components by sample depth (that is, $\mathrm{Fe}$ and $\mathrm{Al}$ are not consistently higher or lower in subsoils versus surface soils across soil types). Similarly, significant variability was found in the WSP and SPSC data across the soil series sampled (Figure 5).

Despite the lack of clear correlation between soil series data and the results presented herein, each of the soil series examined displayed some capacity to retain additional $\mathrm{P}$ in one or both horizons. These findings suggest that soil series may provide a tool to aid in preliminary site evaluations, which can be supported through additional site-specific investigations of soil conditions. For example, Blount silt loam and 
Pewamo silt clay loam occupy $>50 \%$ of a 100,000 ac area in Auglaize County, Ohio. The Blount series appears to exhibit less WSP and more P storage capacity than the Pewamo series in the current data set. Notably, soil-P dynamics depend on land-use history, fertilizer application patterns, farming practices, and other factors. As a result, additional site-specific and regional soils analysis will be required to link soil series mapping information with SPSC across large spatial scales, and a larger data set may prove more useful for evaluating the utility of soil survey data to predict soil-P dynamics.

Figure 5. Relationship between soil series and soil-P dynamics (WSP and SPSC values). Note that, although there is considerable variability in the data, the majority of common soil series in the region displayed some capacity to retain additional $P$. However, P sorption dynamics vary according to site conditions and land-use history.

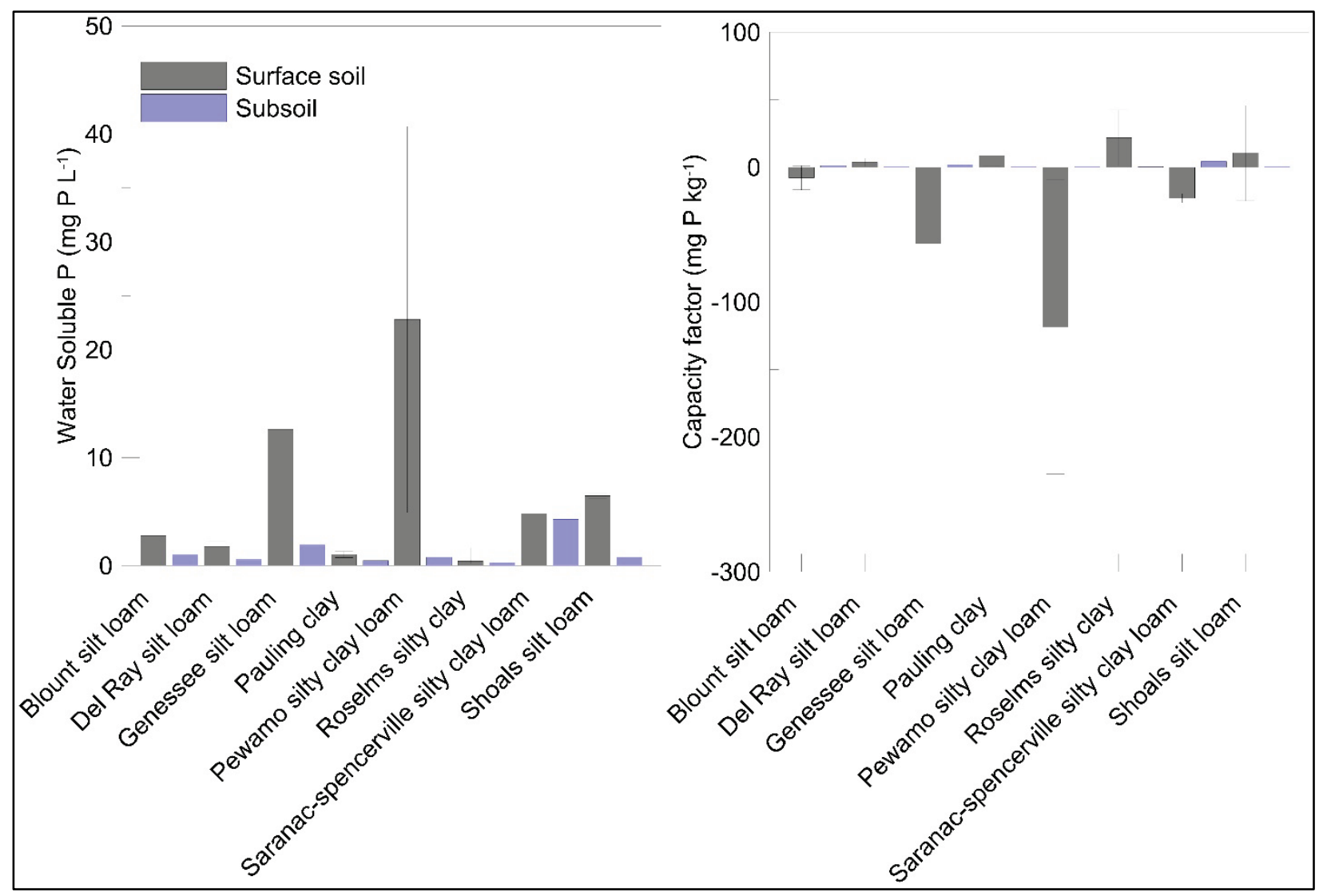

\subsubsection{Prioritizing candidate parcels for wetland BMP development}

Examining soil conditions at the five priority wetland properties yielded a variety of outcomes, with important implications for wetland BMP design and implementation. Notably, site \#21 exhibited PSR values $<0.1$ and positive SPSC in all soils examined, including both surface and subsurface 
soils. As a result, site \#21 displayed the capacity to retain $P$ across all sampled areas (Figure 6), suggesting development of a wetland BMP at that location could be accomplished without soil remediation or soil removal. Note that, while all areas displayed positive SPSC, the magnitude of study results varied between locations (range $=0.02-45.4 \mathrm{mgPkg}^{-1}$ ).

Figure 6. SPSC in surface and subsurface soils at sample location numbers 37,52 , 36,30 , and 21. The green plus signs represent SPSC values $>2 \mathrm{mgPkg}^{-1}$, the yellow triangles represent SPSC between 2 and $0 \mathrm{mgPkg}^{-1}$, and the orange circles represents $<0.0 \mathrm{mgPkg}^{-1}$.

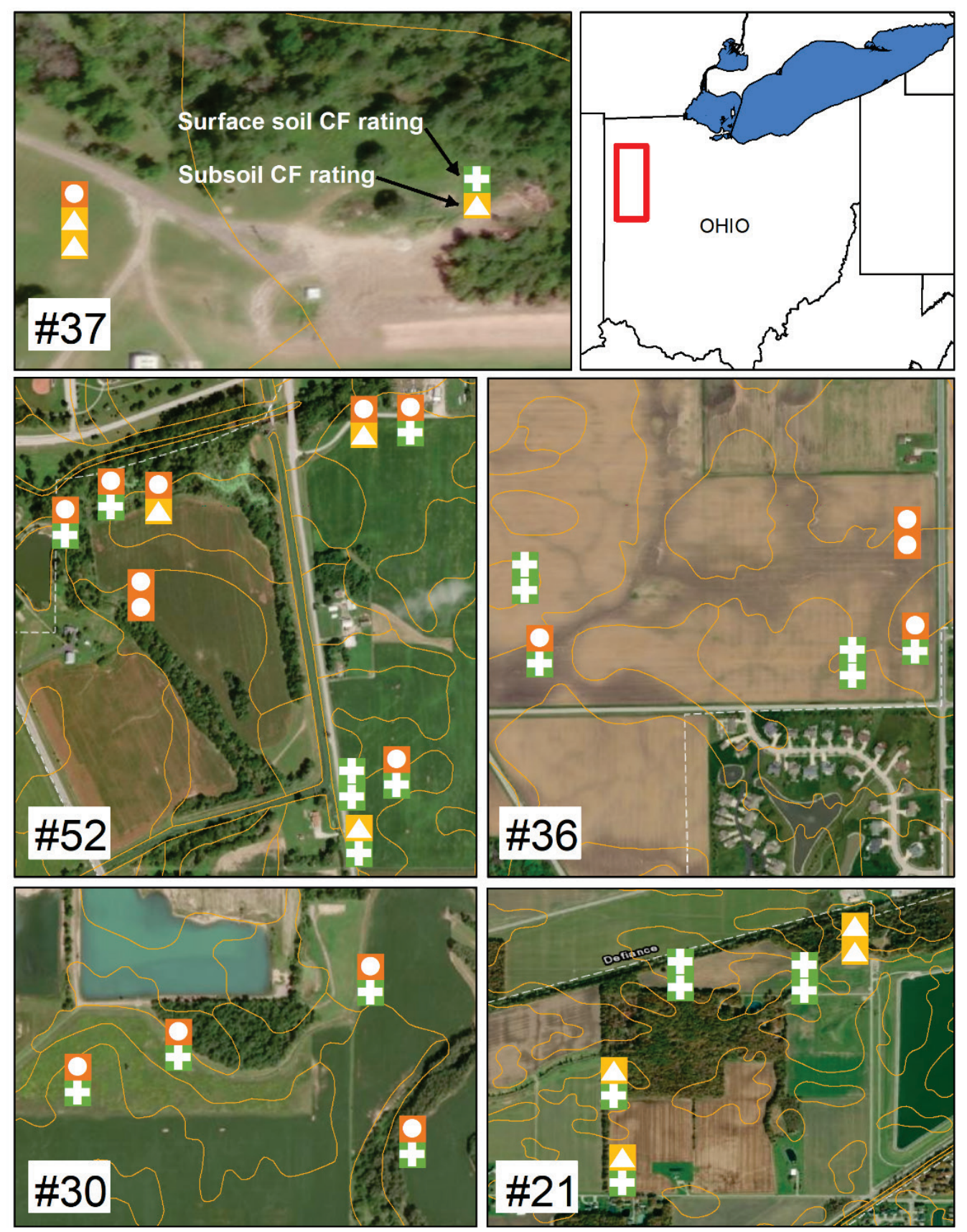


Site \#36 displayed moderate capacity to retain $P$, with two of the five surface soils and four of the five subsurface soils containing positive $P$ sorption capacity (Figure 6). However, one surface soil (\#36-5) was particularly saturated with $\mathrm{P}\left(-773 \mathrm{mgPkg}^{-1}\right)$, representing the highest value observed within the data set. These findings suggest that some areas within site \#36 should be avoided, or surface soils removed, prior to development of a wetland BMP designed for nutrient retention.

All surface soils in location \#30, and a subset of those in location \#52, contained negative sorption SPSC, suggesting a potential source of $\mathrm{P}$. Conversely, the majority of subsurface soils at these two sample locations contained positive sorption SPSC and the capacity for additional $P$ retention. As a result, some surface soils in these locations may require removal or remediation prior to wetland BMP project implementation, whereas most subsurface soils would likely be suitable for further site development.

- Site \#37 exhibited evidence of soil disturbance and historic placement of fill materials, especially in the western portion of the project area. As a result, only two locations were selected for on-site evaluation (Figure 6). Results suggest limited P sorption capacity exists within subsoils, while surface soils varied between potential $P$ sinks and sources. If additional investigation of site \#37 is conducted, the eastern portions of the study area are recommended because of the absence of fill materials.

\subsection{Summary and recommendations}

The SPSC results varied across the five locations examined, with positive, negative, and near-zero values observed. In general, surface soils displayed lower remaining capacity to retain $P$, in agreement with observed vertical stratification of soil P reported in other studies (VanZomeren, et al. 2019; Nair, et al. 2004). However, each location contained some soils with additional $\mathrm{P}$ storage capacity. This variable capacity highlights the need to incorporate on-site measures of soil conditions during wetland BMP site selection and design. The soils investigated at site \#21 were the only property with PSR $<0.1$ and positive SPSC in both the surface and subsurface soils, displaying the highest potential $\mathrm{P}$ sorption capacity across a broad geographic area. Additionally, site \#21 displayed several of the highest $P$ retention capacities observed, with several locations exhibiting SPSC $>45 \mathrm{mgPkg}^{-1}$. As a result of these findings, conducted in concert with 
other analyses, a pilot project is currently underway to design and construct a P-reduction wetland BMP in the vicinity of study location \#21.

Notably, the presence of low SPSC values at a subset of the other candidate parcels should not preclude those areas for consideration as wetland BMP development sites. Management considerations, including design location and construction techniques, may be necessary at locations \#30, \#36, \#37, and $\# 52$ to avoid unintentional $P$ release and maximize $P$ retention. Specific management actions may include avoidance of problematic areas, such as the sample point in the northeastern portion of site \#36, which is particularly saturated with $\mathrm{P}\left(-773 \mathrm{mgPkg}^{-1}\right)$. Alternatively, the application of soil amendments in areas with soils containing near-zero or negative SPSC can increase P storage capacity, although more research is needed to fully investigate the effects of amendments on soil-P dynamics.

The combination of the off-site approaches used to identify candidate parcels in conjunction with the on-site approaches outlined herein proved effective in assessing locations for wetland BMP development potential. The linkage between ground-based, remote-sensing, and modeling techniques will require additional coupling to address large, basin-scale initiatives underway through the GLRI program (Berkowitz, et al. 2020).

An analysis of soil series data was conducted to evaluate the potential to utilize soil map units to predict soil P storage dynamics. Soil series and geological history can be found in appendix A and soil series descriptions in appendix D. Land use for each sample is located in Table B-1. Examining the extractable $\mathrm{Fe}$ and $\mathrm{Al}$ data, no clear pattern differentiates soil $\mathrm{P}$ sorption components by sample depth (that is, $\mathrm{Fe}$ and $\mathrm{Al}$ are not consistently higher or lower in subsoils versus surface soils across soil types). Similarly, significant variability was found in the WSP and SPSC data across the soil series sampled (Figure 5).

Despite the lack of clear correlation between soil series data and the results presented herein, each of the soil series examined displayed some capacity to retain additional $P$ in one or both horizons. These findings suggest that soil series may provide a tool to aid in preliminary site evaluations, which can be supported through additional, site-specific investigations of soil conditions. For example, Blount silt loam and Pewamo silt clay loam occupy $>50 \%$ of a 100,000-acre area in Auglaize County, Ohio. The Blount series appears to exhibit less WSP and more P 
storage capacity than the Pewamo series in the current data set. Notably, soil-P dynamics depend on land-use history, fertilizer application patterns, farming practices, and other factors. As a result, additional site-specific and regional soils analysis will be required to link soil series mapping information with SPSC across large spatial scales, and a larger data set may prove more useful for evaluating the utility of soil survey data to predict soil-P dynamics.

\subsubsection{Prioritizing candidate parcels for wetland BMP development}

Examining soil conditions at the five priority wetland properties yielded a variety of outcomes, with important implications for wetland BMP design and implementation. Notably, site \#21 exhibited PSR values $<0.1$ and positive SPSC in all soils examined, including both surface and subsurface soils. As a result, site \#21 displayed the capacity to retain $P$ across all sampled areas (Figure 6), suggesting development of a wetland BMP at that location could be accomplished without soil remediation or soil removal. Note that, while all areas displayed positive SPSC, the magnitude of study results varied between locations (range $=0.02-45.4 \mathrm{mgPkg}^{-1}$ ). 


\section{Evaluation of SPSC for Wetland BMP Development in Support of the H2Ohio Initiative}

\subsection{Background}

Recent interest has focused on the restoration of wetlands throughout the state of Ohio as part of the H2Ohio initiative. These efforts include development of wetland restoration sites to decrease $\mathrm{P}$ concentrations entering surface waters while improving habitat and providing other ecosystem functions and values. Of particular interest is the reestablishment of historic hydro patterns, fish passages, and functionality of coastal wetlands disconnected from Lake Erie by a series of dikes and other structures. Additionally, the restoration of historic floodplain wetlands previously converted to agricultural uses has the capacity to improve water quality in inland locations. In response, this study investigated the SPSC of both coastal and floodplain wetlands in select locations within the Maumee, Cedar-Portage, and Sandusky watersheds in northwest Ohio.

\subsection{Methods}

Project partners from the Ohio Department of Natural Resources identified study locations according to accessibility and interest in developing wetland restoration projects designed to improve water quality at local and regional scales. This assessment resulted in the selection of eight locations for sampling and analysis (Figure 7). A total of 79 soil samples were collected during November 2019. Once each study location was identified, soil survey maps were used to stratify soil-sampling locations according to the distribution of soil series, focusing on the most widely distributed series mapped within each target parcel. 
Figure 7. H2Ohio sample locations in northern Ohio. (1 mile $=1609.34$ meters $)$

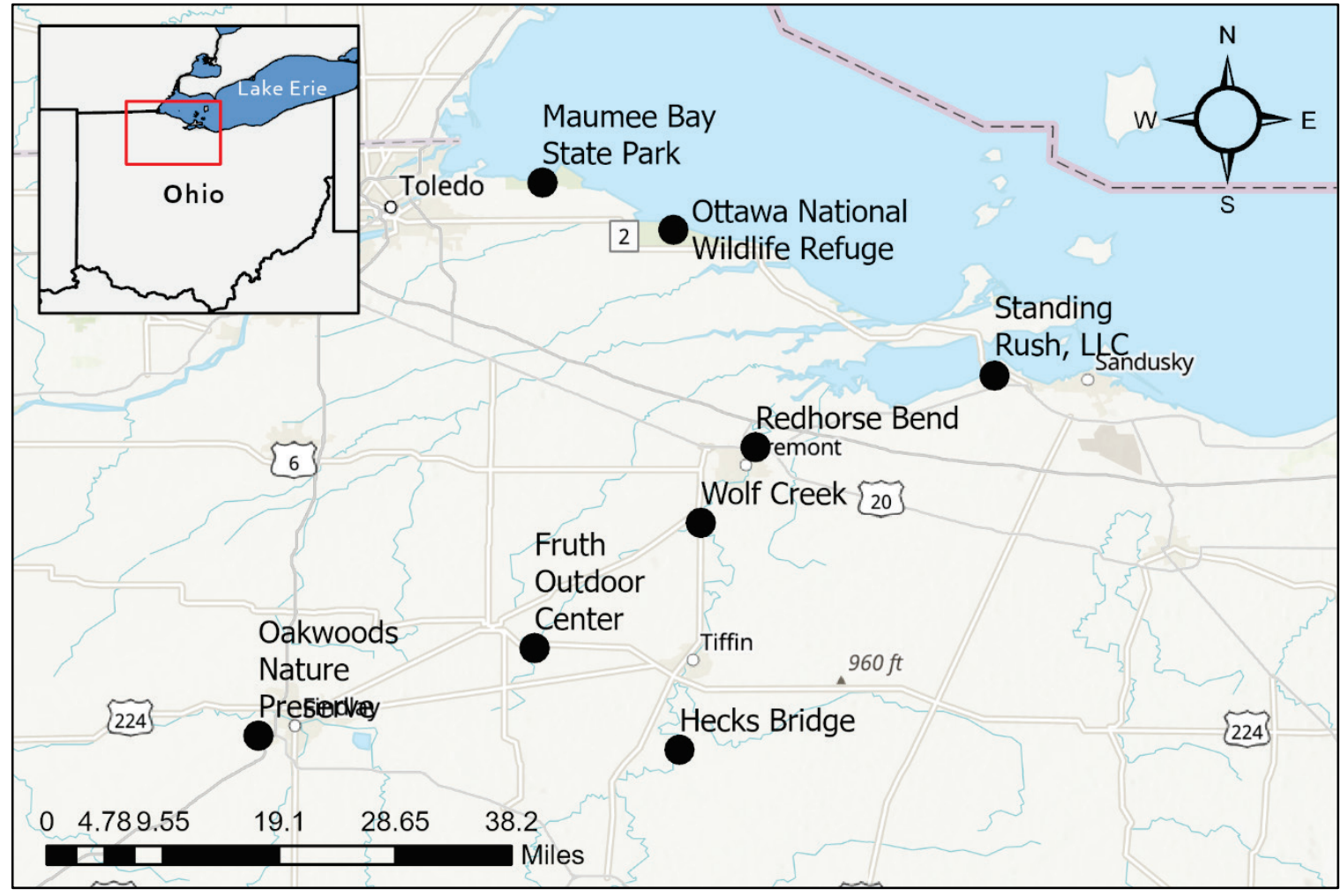

At each location, soil samples were collected from two to four soil horizons closest to the soil surface. This approach has also been used in other studies to account for the stratification of $\mathrm{P}$ in surface soil layers and inform the placement and design of wetland restoration projects (Baker et al. 2017). Soil samples were homogenized, dried at $30^{\circ} \mathrm{C}$, and ground prior to analysis for WSP and Mehlich 3 extraction. Note that the Mehlich 3 extraction differs from the Mehlich 1 extraction used in the previous case study (section 2). The change in extraction methods was made in response to trends in soil nutrient analysis, which are increasingly applying the Mehlich 3 method because it may better reflect plant-available $P$ than Mehlich 1 in many soils. Mehlich 3 is also becoming increasingly more common throughout the midwestern United States region and was selected to better align with these trends. As a result, the data presented in section 2 are not directly comparable to those presented herein.

As in the previous case study, WSP was determined by deionized water extraction for $1 \mathrm{~h}$ followed by filtration through a $0.45 \mu \mathrm{m}$ membrane filter (Kuo 1996; Richardson and Reddy 2013). The WSP concentration analysis was performed using a SEAL AQ2 Automated Discrete Analyzer (SEAL Analytical, West Sussex, England; EPA-145-A Rev. 1). Method detection 
limits were $0.005 \mathrm{mgPL}^{-1}$ for WSP. Mehlich 3-extractable $\mathrm{P}, \mathrm{Fe}$, and $\mathrm{Al}$ were determined by Mehlich 3 soil solution $\left(0.2 \mathrm{M} \mathrm{CH}_{3} \mathrm{COOH}+0.25 \mathrm{M}\right.$ $\left.\mathrm{NH}_{4} \mathrm{NO}_{3}+0.015 \mathrm{M} \mathrm{NH}_{4} \mathrm{~F}+0.013 \mathrm{M} \mathrm{HNO}_{3}+0.001 \mathrm{M} \mathrm{EDTA}\right)$ extraction for $5 \mathrm{~min}$, followed by filtration through a $0.45 \mu \mathrm{m}$ membrane filter (Mehlich 1984; Reddy 2013). Mehlich 3-extractable P was analyzed using a Seal AQ2 Automated Discrete Analyzer (SEAL Analyzer, West Sussex, England; AGR-201-A Rev. 1), with a method detection limit of 0.015 $\mathrm{mgPL}^{-1}$. Mehlich 3-extractable $\mathrm{Fe}$ and $\mathrm{Al}$ were analyzed using combustion inductively coupled plasma-atomic emission spectroscopy (United States Environmental Protection Agency 1994).

The following equation was used to determine SPSC and PSR using the following generalized formulas described in Nair et al. (2011):

$\operatorname{SPSC}\left(\mathrm{mg} \mathrm{kg}^{-1}\right)=\left(\right.$ Threshold PSR $\mathrm{M3}_{3}-$ Soil PSR $\left._{M 3}\right)\left(\frac{[\text { Mehlich } 3 \mathrm{Fe}]}{56}+\frac{[\text { Mehlich } 3 \mathrm{Al}]}{27}\right) 31$,(3)

where the PSR is calculated as the molar ratio of Mehlich 3-extractable P to Mehlich 3-extractable Fe and $\mathrm{Al}$

$$
P S R_{M 3}=\frac{\left(\frac{[\text { Mehlich } 3 \mathrm{P}]}{31}\right)}{\left(\frac{[\text { Mehlich } 3 \mathrm{Fe}]}{56}+\frac{[\text { Mehlich } 3 \mathrm{Al}]}{27}\right)} .
$$

The current analysis applied a PSR critical threshold value of 0.01 on the basis of the interpretation of the data presented in Figure 8. This critical threshold was selected for three reasons: (1) WSP increased above the 0.01 threshold, (2) the threshold resulted in SPSC decreasing with increases in WSP, and (3) the threshold yielded negative SPSC values in a sample location exhibiting ongoing or recent agricultural production activities, thus adhering to expected results. Note that threshold PSR values vary with soil type and extractable $\mathrm{Fe}$ and $\mathrm{Al}$ concentrations, with other studies having used thresholds of 0.10, for example (Dari et al. 2018). However, many of those studies were based on acidic soils, which typically contain lower Al and Fe concentrations than those evaluated herein. Thus, the application of a 0.01 PSR threshold in the current report is designed to reflect the higher $\mathrm{pH}$ values of soils in the study area. The lower threshold values also reduce SPSC values, providing a conservative estimate of $P$ storage potential while supporting relative comparisons across a broad range of study location 
conditions (for example, coastal marshes, floodplains, forested areas, active agricultural fields, completed restoration projects).

Figure 8. Relationship between WSP and PSR ${ }_{M 3}$ used to identify the critical threshold value of 0.01 , above which increases in WSP are observed (left panel). Relationship between SPSC and WSP also followed expected patterns, as WSP increased when SPSC was below zero (right panel).
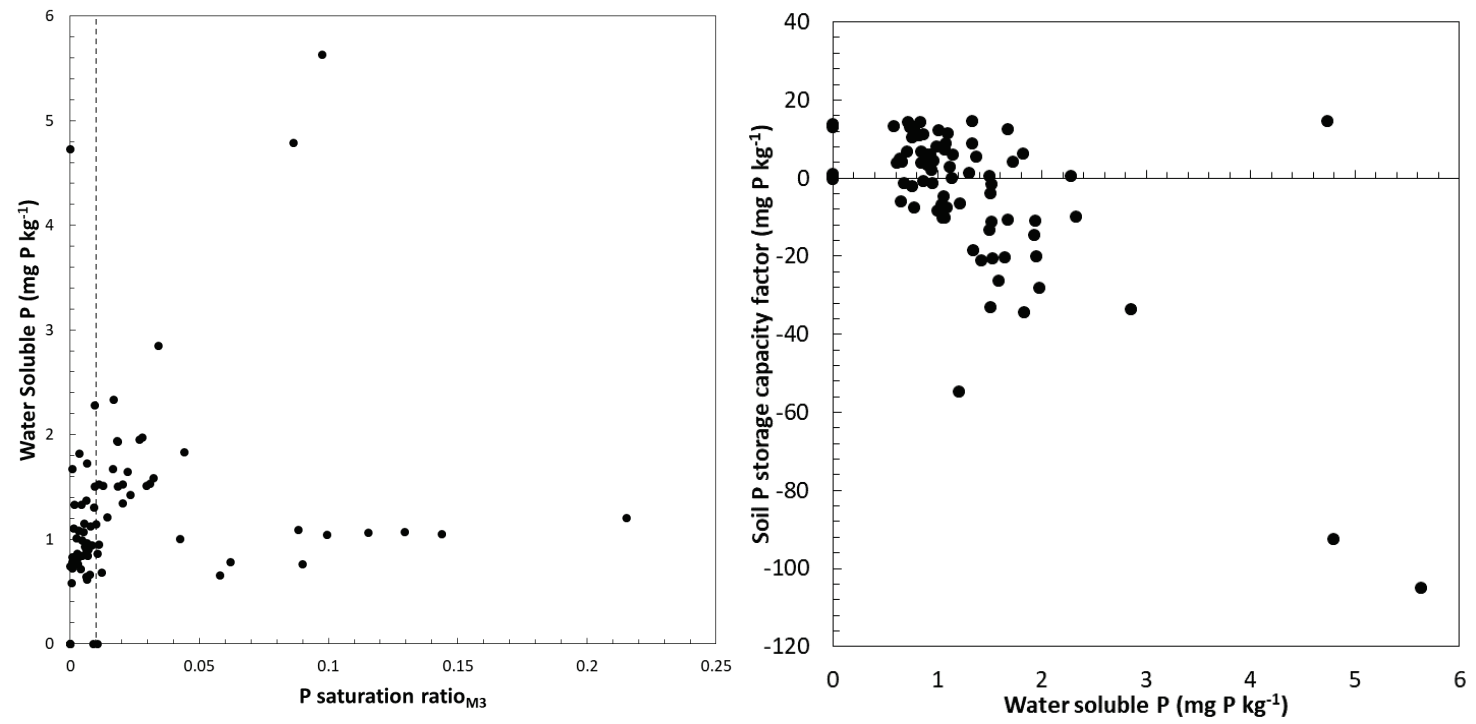

\subsection{Results}

The soils within the study locations are comprised of silty clay loam, silty clay, silt loam, and ground moraine from the Nappanee, Toledo, Rossburg, Mentor, Lenawee, Blount, Chagrin, and Shoal series (Soil Survey Staff 2020). The soils in the study area developed from lake deposits, Wisconsinan (14,000-24,00o years old) ground moraine, wave-planed ground moraine, and ridge moraine geologic units (Larsen, Shrake, and Swinford 2005; Pavey et al. 2005; Venteris et al. 2008). In general, surface deposits consist of Wisconsinan-aged silt, clay, or loam tills with varying amounts of carbonate. In some coastal locations, marl deposits were encountered, reflecting the influence of historic occurrences of epiphytic bacteria in shallow surface waters and lake fringes. Detailed information regarding the soil series, geologic substrates, and analytical soil testing results associated with each sample location can be found in Table C-2.

Site conditions, representative soil photos, and visualizations of SPSC concentrations are displayed in Figures 9-16. Study locations exhibited a range of SPSC values ( -105 to $14.0 \mathrm{mgPkg}^{-1}$ ), which is not unexpected given the variety of landforms and land-use patterns included in the study. 
Despite the observed variability in SPSC, seven of the eight study locations exhibited some capacity to adsorb additional P (that is, SPSC values $>0.0 \mathrm{mgPkg}^{-1}$ ). Additionally, it should be noted that the SPSC approach only considers soil surface adsorption processes, and all study sites are anticipated to sequester particulate $P$ if surface waters are introduced with adequate holding times for sediment entrapment and settling.

As seen in other studies, SPSC values remained lower in surface soils (average \pm standard error $=-9.2 \pm 4.2 \mathrm{mgPkg}^{-1}$ ) than in subsurface layers $\left(1.3 \pm 2.4 \mathrm{mgPkg}^{-1}\right)$, and SPSC generally increased with soil horizon depth (full data set available in Table C-2). For example, $61 \%$ of surface soil samples exhibited near-zero or negative SPSC, compared to $43 \%$ of subsurface soils. Soil P stratification with depth is common, especially in operational and historically agricultural areas (Baker et al. 2017).

Results varied across landscape positions, with coastal soils generally exhibiting lower SPSC $\left(-0.70 \pm 1.2 \mathrm{mgPkg}^{-1}\right)$ than inland, floodplain locations within the WLEB $\left(11.4 \pm 4.0 \mathrm{mgPkg}^{-1}\right)$ (Table 1). This report represents one of the first studies to apply the SPSC approach to inland coastal marshes, and additional work will be required to contextualize results from coastal wetland systems in Ohio and elsewhere.

However, the results provide immediate utility for conducting relative comparisons between study locations and evaluating soil conditions within each study parcel. Coastal systems in the region have been subject to a variety of alterations, including direct and indirect nutrient inputs from agriculture and other sources (Heath 1992; Wang and Mitsch 1998). As a result, the lower SPSC values in those areas are not unexpected. Land use influenced SPSC, as observed with the values of $-20.2 \pm 7.1 \mathrm{mgPkg}^{-1}$ soil in active agricultural areas compared with other land cover categories (Table 2). 
Table 1. Summary of SPSC $\left(\mathrm{mgkg}^{-1}\right)$ values at each study location. (SE = standard error).

\begin{tabular}{|l|l|l|l|l|l|}
\hline Study location & $\begin{array}{l}\text { Average SPSC } \pm \\
\text { SE }\end{array}$ & Range & $\begin{array}{l}\text { Sample } \\
\text { size }\end{array}$ & Landform & Watershed \\
\hline Maumee Bay State Park & $-7.3 \pm 3.3$ & -54.6 to 1.2 & 10 & Coastal & Portage \\
\hline Ottawa National Wildlife Refuge & $7.1 \pm 1.3$ & 0 to 14.3 & 11 & Coastal & Portage \\
\hline Standing Rush, LLC & $1.3 \pm 2.8$ & -20 to 11.3 & 16 & Coastal & Sandusky \\
\hline Oakwoods Nature Preserve & $-39.6 \pm 10.2$ & -105 to -11.1 & 14 & Inland & Maumee \\
\hline Wolf Creek & $2.5 \pm 3.4$ & -14.6 to 13.9 & 4 & Inland & Sandusky \\
\hline Fruth Outdoor Center & $8.8 \pm 2.2$ & 2.9 to 12.5 & 10 & Inland & Sandusky \\
\hline Redhorse Bend & $-0.7 \pm 3.6$ & -11 to 6.1 & 10 & Inland & Sandusky \\
\hline Hecks Bridge & $2.1 \pm 3.8$ & -28.2 to 14.7 & 4 & Inland & Sandusky \\
\hline
\end{tabular}

Table 2. Mean SPSC values ( $\mathrm{mgkg}^{-1}$ ) within each land use observed in the study. (SE = standard error; $n=$ number of samples.)

\begin{tabular}{|l|l|l|l|}
\hline Land use & SPSC & SE & $n$ \\
\hline Active agriculture & -20.2 & 7.1 & 20 \\
\hline Emergent wetland & -4.8 & 6.0 & 4 \\
\hline Forested marsh & -1.5 & 4.0 & 6 \\
\hline Emergent marsh & -0.5 & 2.2 & 31 \\
\hline Forested wetland & 5.9 & 1.8 & 14 \\
\hline Recreational field & 7.6 & 3.6 & 4 \\
\hline
\end{tabular}


Figure 9. Standing Rush site conditions, sample locations, soil map units, and SPSC.

The green plus sign represents SPSC values $>2 \mathrm{mgPkg}^{-1}$, the yellow triangles represent SPSC between 2.0 and $0.0 \mathrm{mgPkg}^{-1}$, and the orange circles represent $<0.0 \mathrm{mgPkg}^{-1}$ in surface and subsurface samples.
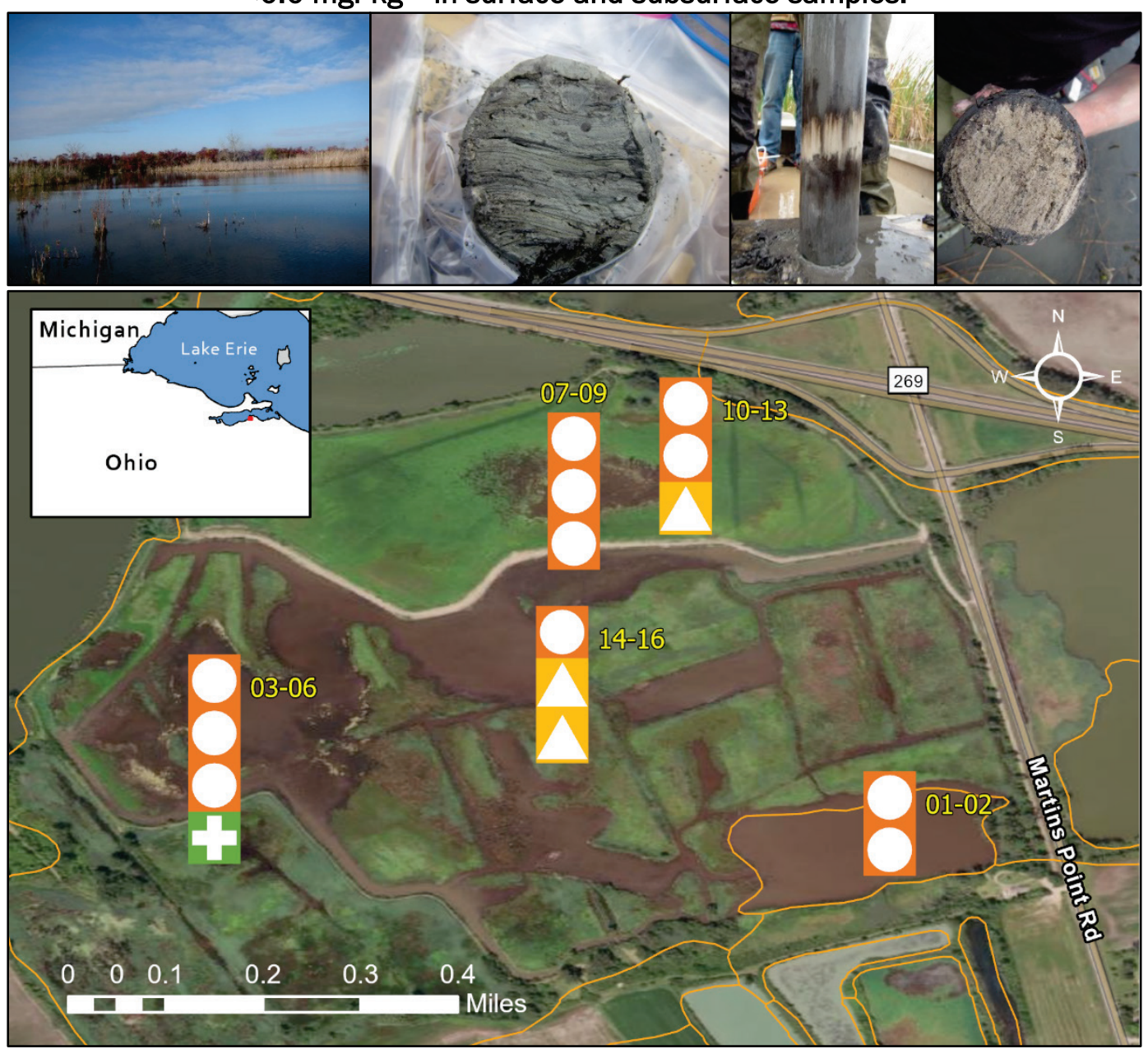
Figure 10. Maumee Bay State Park site conditions, sample locations, soil map units, and SPSC. The green plus sign represents SPSC values $>2 \mathrm{mgPkg}^{-1}$, and the orange circles represent $<0.0 \mathrm{mgPkg}^{-1}$ in surface and subsurface samples.
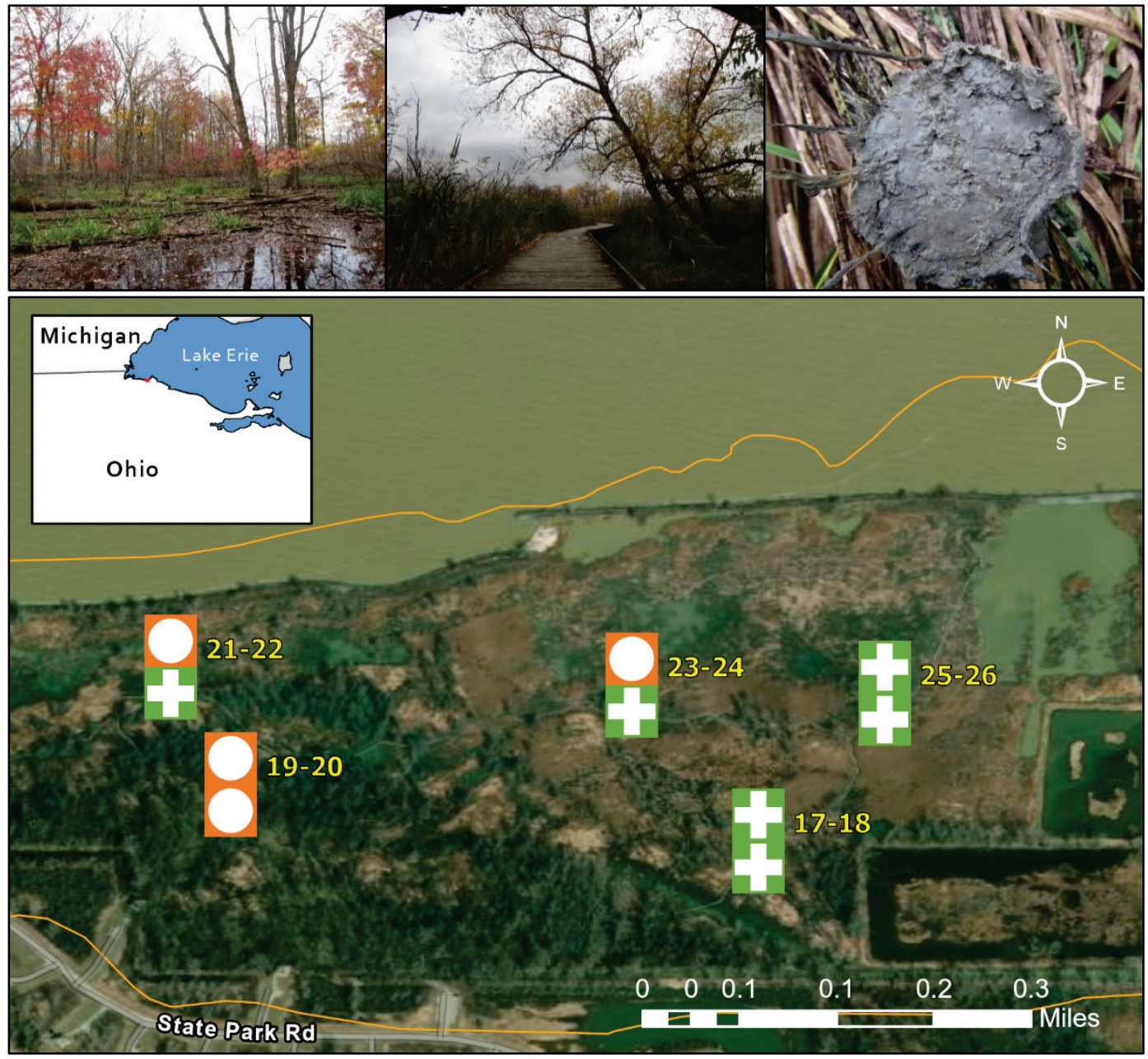
Figure 11. Ottawa National Wildlife Refuge site conditions, sample locations, soil map units, and SPSC. The green plus signs represent SPSC values $>2$ mgPkg $^{-1}$, and the orange circle represents $<0.0 \mathrm{mgPkg}^{-1}$ in surface and subsurface samples.
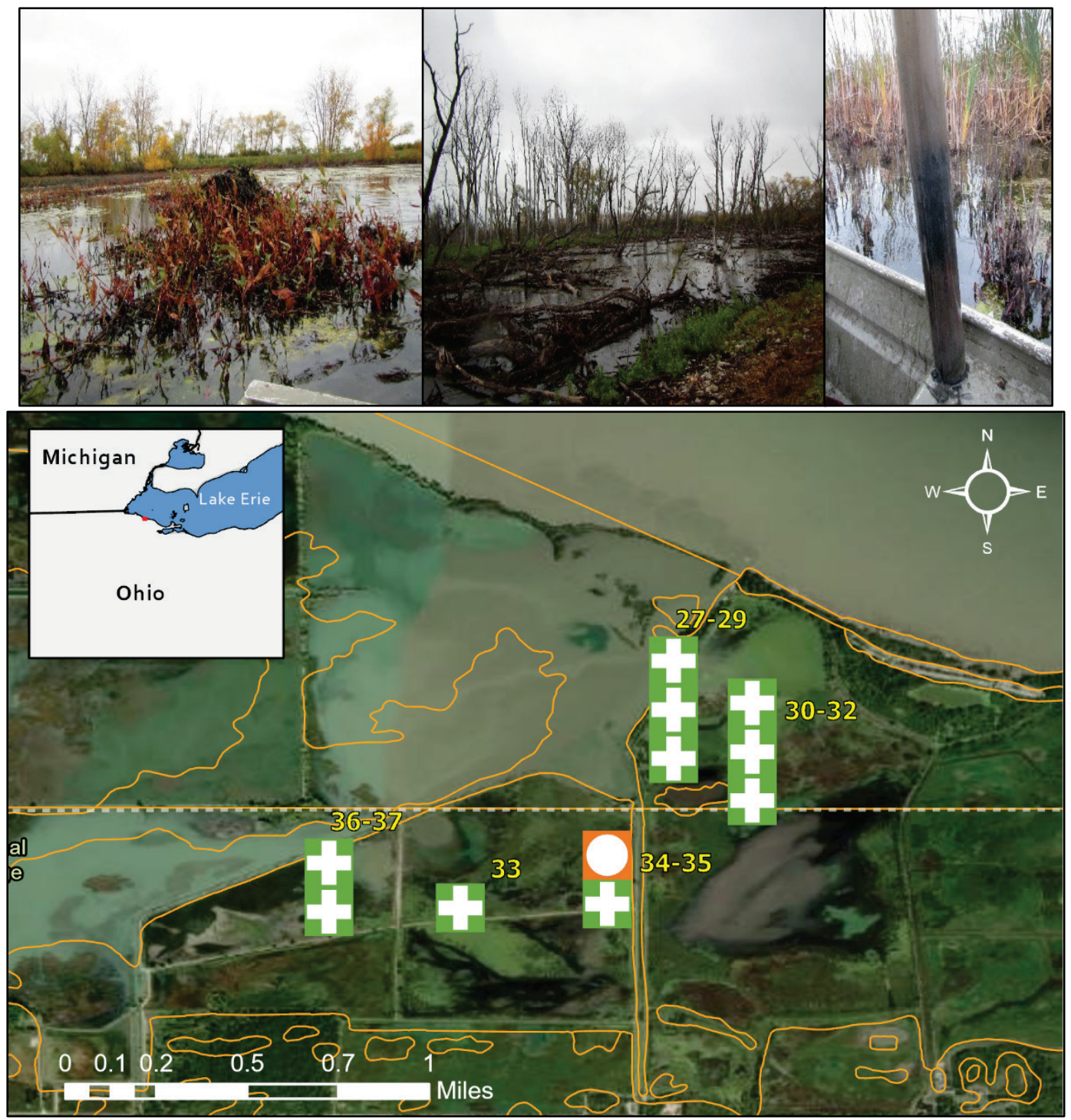
Figure 12. Redhorse Bend site conditions, sample locations, soil map units, and SPSC. The orange circles represent $<0.0 \mathrm{mgPkg}^{-1}$ in surface and subsurface samples.

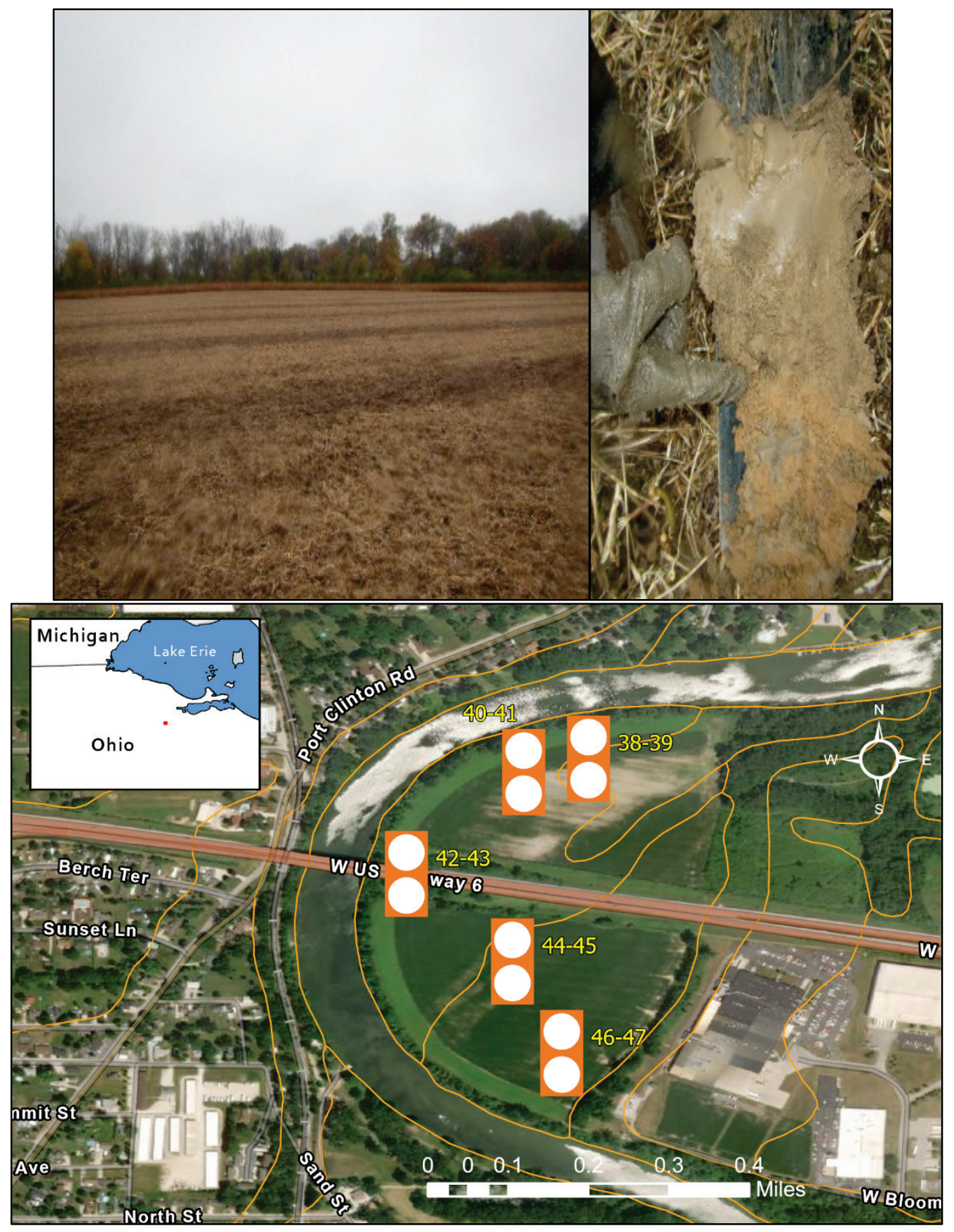


Figure 13. Fruth Outdoor Center site conditions, sample locations, soil map units, and SPSC. The green plus signs represent SPSC values $>2 \mathrm{mgPkg}^{-1}$, the yellow triangle represents SPSC between 2.0 and $0.0 \mathrm{mgPkg}^{-1}$, and the orange circles represent $<0.0 \mathrm{mgPkg}^{-1}$ in surface and subsurface samples.

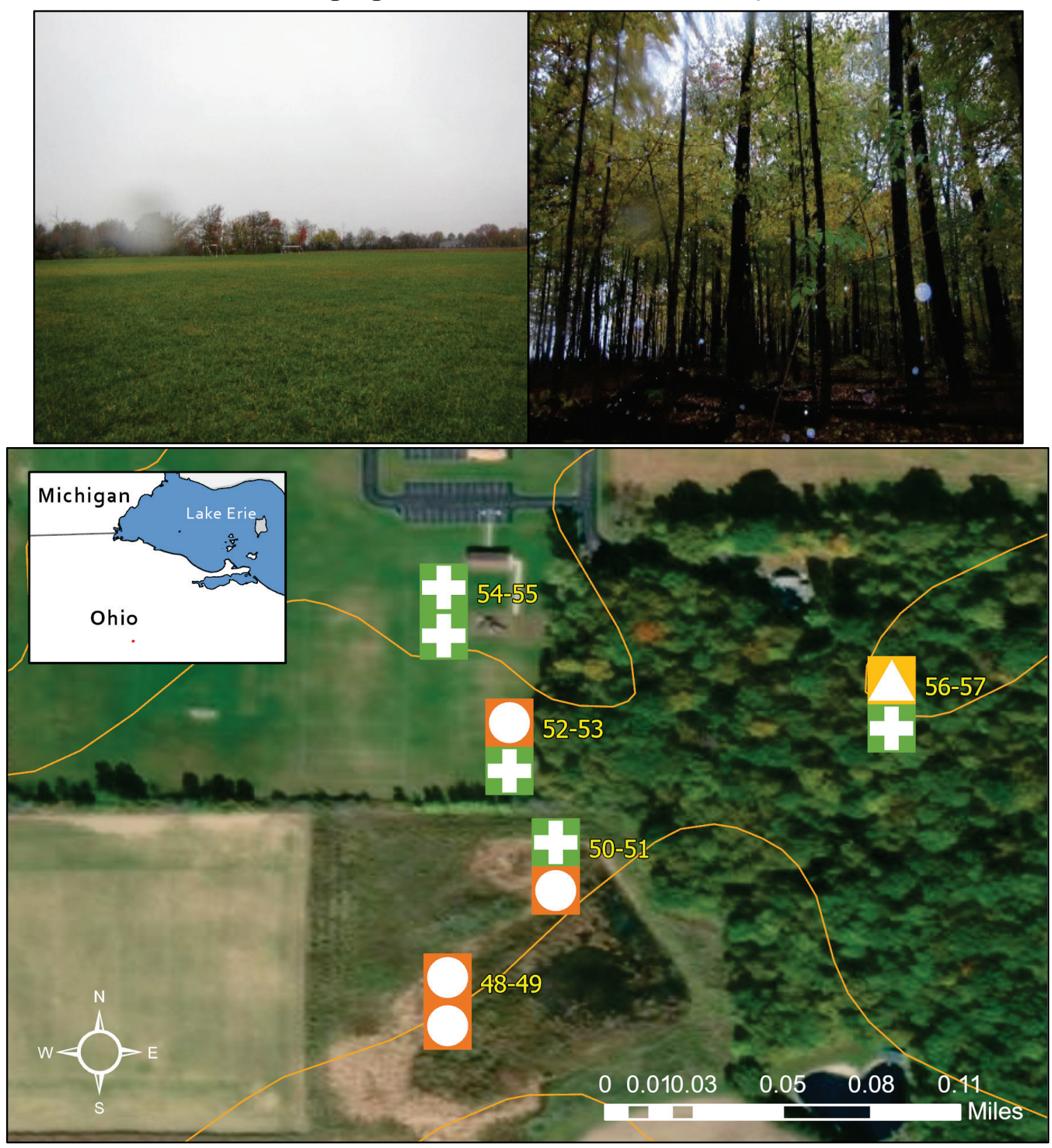


Figure 14. Hecks Bridge site conditions, sample locations, soil map units, and SPSC. The green plus signs represent SPSC values $>2 \mathrm{mgPkg}^{-1}$ in surface and subsurface samples.
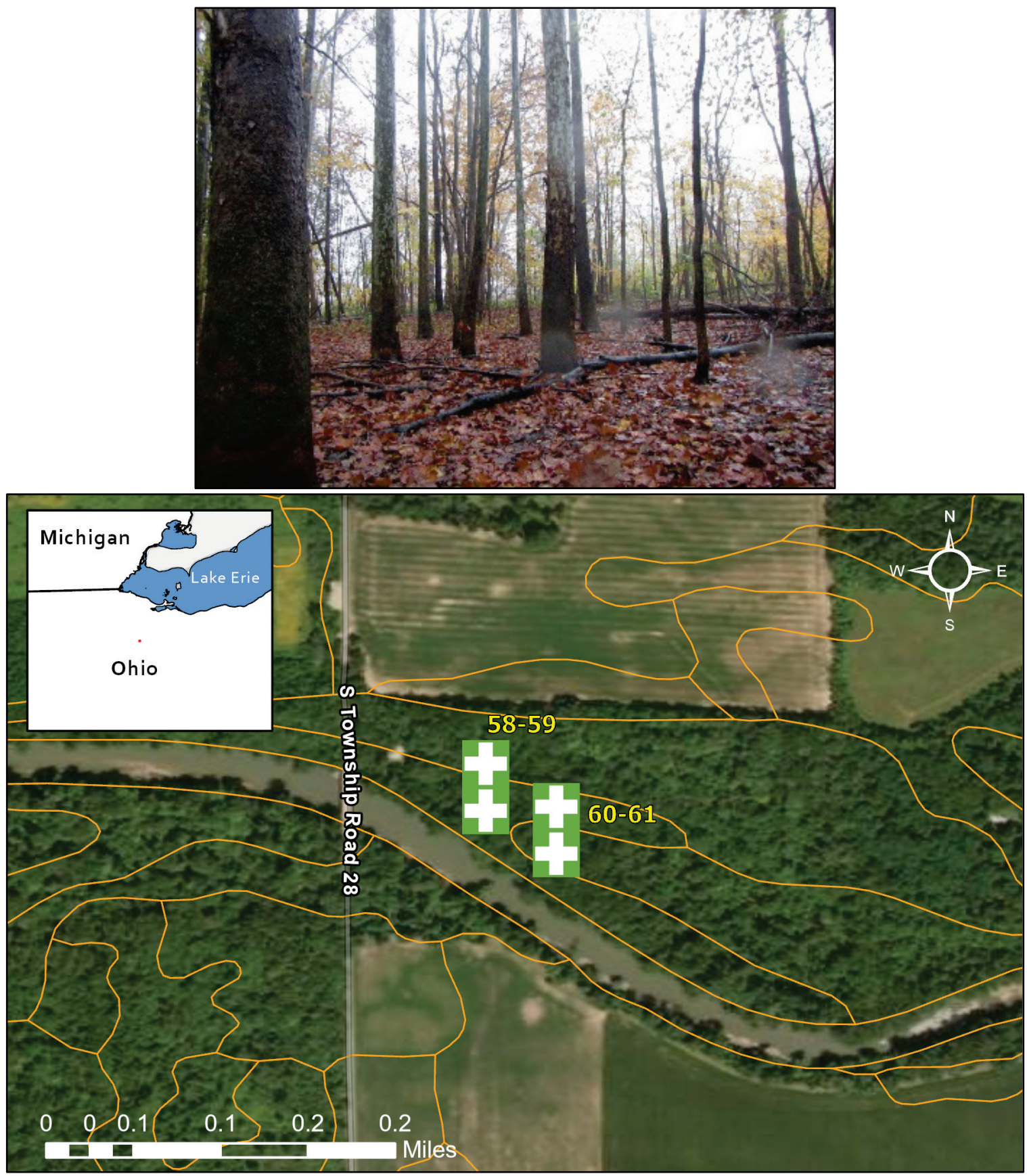
Figure 15. Wolf Creek site conditions, sample locations, soil map units, and SPSC. The green plus sign represents SPSC values $>2 \mathrm{mgPkg}^{-1}$, the yellow triangles represent SPSC between 2.0 and $0.0 \mathrm{mgPkg}^{-1}$, and the orange circle represents $<0.0 \mathrm{mgPkg}^{-1}$ in surface and subsurface samples.
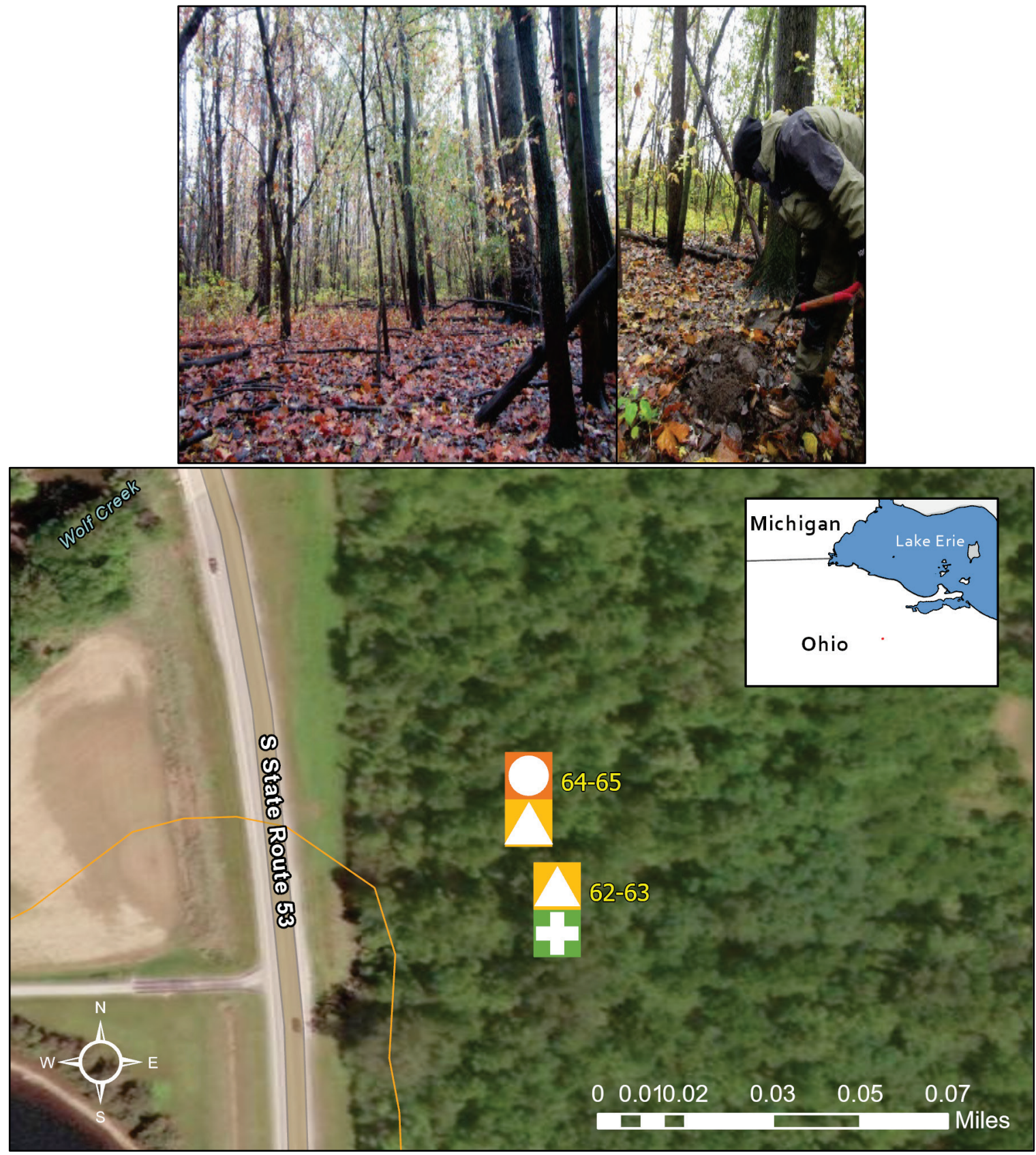
Figure 16. Oakwoods Nature Preserve site conditions, sample locations, soil map units, and SPSC. The green plus signs represent SPSC values $>2 \mathrm{mgPkg}^{-1}$, and the orange circles represent $<0.0 \mathrm{mgPkg}^{-1}$ in surface and subsurface samples.
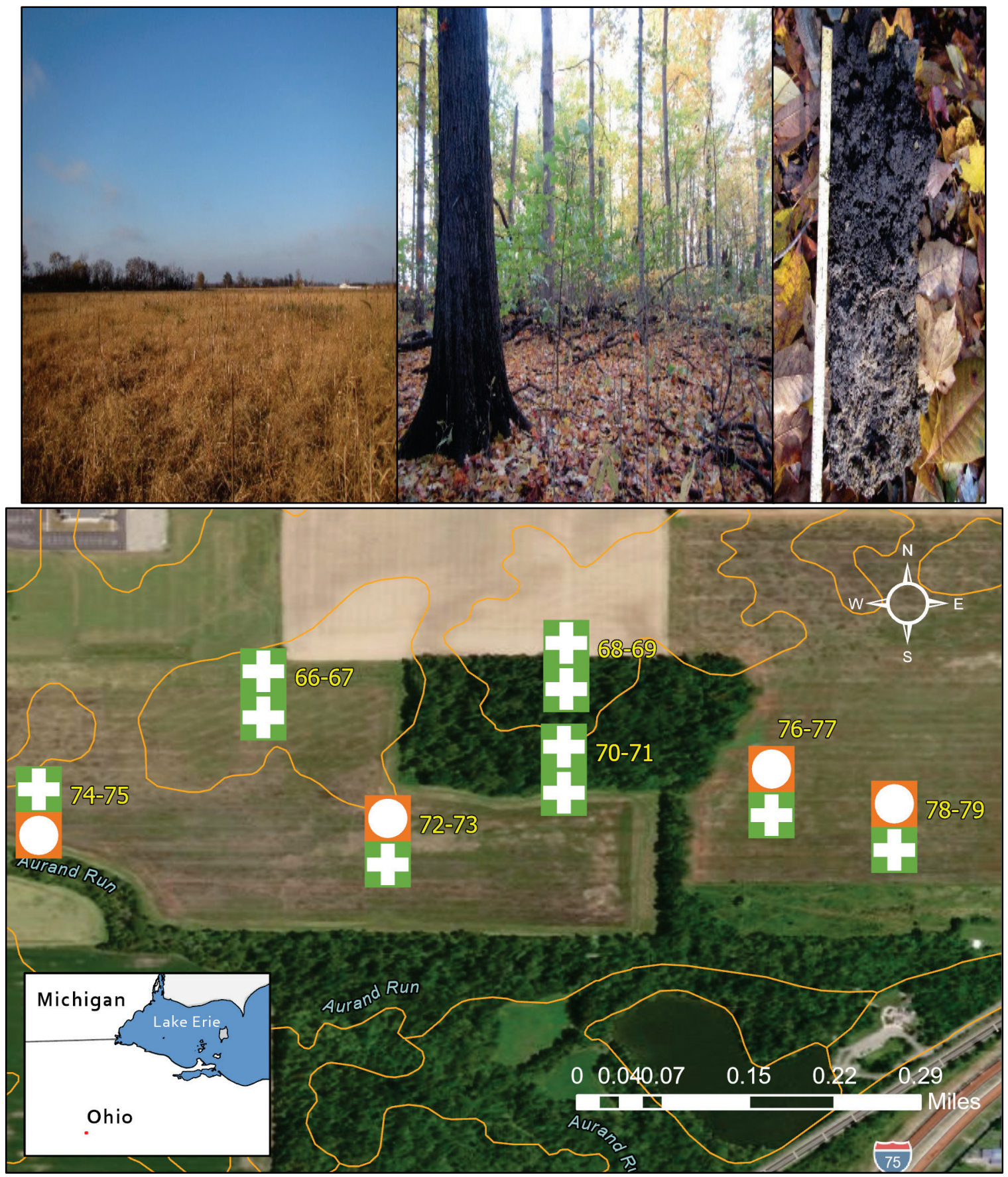

These results support relative comparisons that can be applied to evaluate $\mathrm{P}$ sorption potentials within a single parcel or at regional scales. For example, within the Maumee Bay State Park data set, SPSC values were higher in the eastern portion of the study area (Figure 10) than in other areas. This difference suggests that additional $\mathrm{P}$ sorption would be expected in the 
eastern portion if P-rich waters were introduced into the marsh. Results can also guide the design of future restoration or management activities within a single parcel. For example, four of the five soil locations examined at Maumee Bay State Park exhibited positive SPSC values in the subsoil horizons, while three of five surface soils yielded negative SPSC values. This analysis helps to identify areas where avoidance, removal, or amendment of select soil layers could increase the P storage capacity in the study area. Examining the Fruth Outdoor Center data (Figure 13) highlights this approach. Negative SPSC values were identified in the vicinity of the existing restored emergent wetland (data points 48-49, 51), and positive SPSC values occurred within the recreation field (data points 53, 54-55). These positive values suggest that the recreation field represents an opportunity for additional wetland restoration implementation within that parcel-especially if the surface soils near data point 52 can be excavated and removed during project construction.

The results of this study can also help rank potential wetland restoration projects to maximize water-quality benefits. For example, the Redhorse Bend location exhibited negative SPSC in all samples, while the Heck's Bridge site displayed positive SPSC in all samples (Figure 12 and Figure 14, respectively). These data suggest that wetland development projects conducted at Heck's Bridge have a higher likelihood of adsorbing additional $\mathrm{P}$ while minimizing the risk of $\mathrm{P}$ release. Similarly, the Ottawa National Wildlife Refuge displayed higher SPSC values than the Standing Rush marsh, helping to further refine and prioritize management plans along the coast of Lake Erie. Additional research may be required for the Standing Rush marsh because of the unique historical occurrence of epiphytic bacteria and accumulation of marl, resulting in soil processes that limit $\mathrm{Fe}$ and $\mathrm{Al}$ accumulation.

Soil series information has been applied in a variety of contexts to extrapolate study results to broader spatial scales. The current analysis suggests that land use provides a better predictor of SPSC than soil series. For example, variances of the Toledo series occurred at four of the eight sample locations and yielded a wide range of SPSC values (-92.3 to 14.3 $\left.\mathrm{mgPkg}{ }^{-1}\right)$, with the lowest values $\left(<-32.4 \mathrm{mgPkg}^{-1}\right)$ occurring in active agricultural areas. However, as the availability of SPSC data in the region grows, an analysis of soil survey information may prove beneficial using larger data sets than currently available. 


\subsection{Summary and recommendations}

The SPSC approach, while providing informative data, is not designed to be the sole basis for evaluation of potential wetland development and restoration sites. The SPSC method has proven useful for evaluating soil P sorption dynamics, is relatively expedient and inexpensive, and can be applied in multiple capacities (for example, survey of potential project areas, identify areas for avoidance or remediation). However, the SPSC approach does not account for particulate $\mathrm{P}$ fate and transport, surfacewater residence times, $\mathrm{P}$ loading rates within a given project area, or a variety of other factors related to wetland P-reduction strategies. As such, the results presented herein should be used to supplement other data streams and should not be the only characteristic considered when making determinations. 


\section{Conclusions}

Soils within the study areas exhibited a range of SPSC, reflecting the ability of wetlands to operate as potential $\mathrm{P}$ sinks or sources in response to landscape position and land-use history. The majority of study locations exhibited some capacity to sequester additional $\mathrm{P}$ through soil adsorption. Additionally, the analysis supports development of rankings and comparative analysis within a specific parcel, informing management through design, avoidance, removal, or remediation of potential legacy $\mathrm{P}$ sources. The data herein support relative comparisons between potential wetland BMP development properties. These results, in conjunction with other data sources, can be used to target, prioritize, justify, and improve decision-making for wetland management activities. More research will be required to (1) fully understand the implications of the SPSC approach across soil types, including coastal wetlands, which have not received adequate attention; (2) develop better relationships or models linking field results with predictors of SPSC, including soil series and land-use characteristics; (3) build regional inventories of SPSC to extrapolate results to larger spatial scales; and (4) further incorporate soil testing into the large water-quality improvement initiatives such as GLRI and the H2Ohio program. 


\section{Bibliography}

Baker, David B., Laura T. Johnson, Remegio B. Confesor, and John P. Crumrine. 2017. "Vertical Stratification of Soil Phosphorus as a Concern for Dissolved Phosphorus Runoff in the Lake Erie Basin.” Journal of Environmental Quality 46 (6): 12871295. https://doi.org/10.2134/jeq2016.09.0337.

Berkowitz, Jacob F., Derek A. Schlea, Christine M. VanZomeren, and Chelsie M.W. Boles. 2020. "Coupling Watershed Modeling, Public Engagement, and Soil Analysis Improves Decision Making for Targeting P Retention Wetland Locations." Journal of Great Lakes Research 46(5): 1331-1339. https://doi.org/10.1016 /j.jglr.2020.06.016.

Bosch, Nathan S., J. David Allan, David M. Dolan, Haejin Han, and R. Peter Richards. 2011. "Application of the Soil and Water Assessment Tool for Six Watersheds of Lake Erie: Model Parameterization and Calibration." Journal of Great Lakes Research 37 (2): 263-271. https://doi.org/10.1016/j.jglr.2011.03.004.

Bosch, Nathan S., Mary Anne Evans, Donald Scavia, and J. David Allan. 2014. "Interacting Effects of Climate Change and Agricultural BMPs on Nutrient Runoff Entering Lake Erie.” Journal of Great Lakes Research 40 (3): 581-589, https://doi.org/10.1016/j.jglr.2014.04.011.

Currie, Steven J, Christine M. Vanzomeren, and Jacob F. Berkowitz. 2017. Utilizing wetlands for Phosphorus Reduction in Great Lakes Watersheds: A Review of Available Literature Examining Soil Properties and Phosphorus Removal Efficiency. ERDC/EL SR-17-4. Vicksburg, MS: US Army Engineer Research and Development Center. http://dx.doi.org/10.21079/11681/24838.

Dari, Biswanath; Vimala D Nair; Andrew N. Sharpley; Peter Kleinman; Dorcas Franklin; Willie G. Harris. 2018. "Consistency of the Threshold Phosphorus Saturation Ratio Across a Wide Geographic Range of Acid Soils.” Agrosystems, Geosciences and Environment 1(1): 1-8. https://doi.org/10.2134/age2018.08.0028.

Dunn, Olive Jean. 1964. "Multiple Comparisons Using Rank Sums.” Technometrics 6 (3): 241-252. https://doi.org/10.1080/00401706.1964.10490181.

Heath, Robert T. 1992. "Nutrient dynamics in Great Lakes Coastal Wetlands: Future Directions." Journal of Great Lakes Research 18 (4): 590-602. https://doi.org /10.1016/So380-1330(92)71324-0.

Kleinman, Peter A. J., Andrew N. Sharpley, Paul J. A. Withers, Lars Bergstrom, Laura T. Johnson, and Donnacha G. Doody. 2015. "Implementing Agricultural Phosphorus Science and Management." Ambio 44 (supplement 2): 297-310. https://doi.org/10.1007/s13280-015-0631-2

Kuo, Shiou. 1996. "Phosphorus." In Methods of Soil Analysis Part 3 Chemical Methods SSSA 869-919. https://doi.org/10.2136/sssabookser5.3.c32.

Larsen, G. E., D. L. Shrake, and E. M. Swinford. 2005. "Surficial Geology of the Ohio Portion of the Toledo 30 X 60-Minute Quadrangle, Scale 1:100,00o." Columbus: Ohio Division of Geological Survey. 
Maccoux, Matthew J., Alice Dove, Sean M. Backus, and David M. Dolan. 2016. “Total and Soluble Reactive Phosphorus Loadings to Lake Erie: A Detailed Accounting By Year, Basin, Country, And Tributary.” Journal of Great Lakes Research 42 (96): 1151-1165. https://doi.org/10.1016/j.jglr.2016.08.005.

Mehlich, Adolph. 1984. "Mehlich-3 Soil Test Extractant: A Modification of Mehlich-2 Extractant." Communications in Soil Science and Plant Analysis 15 (12):14091416. https://doi.org/10.1080/00103628409367568.

Michalaka, Anna M, Eric J Anderson, Dimitry Beletsky, Steven Boland, Nathan S Bosch, Thomas B Bridgeman, Justin D Chaffin, et al. 2013. "Record-Setting Algal Bloom in Lake Erie Caused by Agricultural and Meteorological Trends Consistent with Expected Future Conditions." PNAS Early Edition 110 (16): 6448-6452. https:// doi.org/10.1073/pnas.1216006110.

Nair, Vimala D., K. M. Portier, D. A. Graetz, and M. L. Walker. 2004. "An Environmental Threshold for Degree of Phosphorus Saturation in Sandy Soils.” Journal of Environmental Quality 33 (1): 107-113. https://doi.org/10.2134/jeq2004.1070.

Nair, Vimala D., Willie G. Harris, Debolina Chakraborty, and Myrlène Chrysostome. 2011. "Understanding Soil Phosphorus Storage Capacity." SL336. EDIS 2011 (1): 1-4. https://journals.flvc.org/edis/article/view/118870.

Oklin, Ingram. 1960. Contributions to probability and statistics; essays in honor of Harold Hotelling. Stanford, California: Stanford University Press. https://epubs .siam.org/doi/10.1137/1003016.

Pavey, R. R., G. E. Larsen, E. M. Swinford, and K. E. Vorbau. 2005. "Surficial Geology of the Lorain and Put-in-Bay 30 X 60-Minute Quadrangles. Vol. 1:100,00o.” Columbus: Ohio Division of Geological Survey.

Reddy, K. Ramesh, M.W. Clark, Ronald D. DeLaune, and M. Kongchum. 2013. "Physicochemical Characterization of Wetland Soils." In Methods in Biogeochemistry of Wetlands. SSSA Book Series No. 10, 41-54. https://doi.org/10.2136/sssabookser10.c3.

Richardson, Curtis J., and K. Ramesh Reddy. 2013. "Methods for Soil Phosphorus Characterization and Analysis of Wetland Soils." In SSSA Book Series No. 1o, 603-638. https://doi.org/10.2136/sssabookser10.c32.

Scavia, Donald, Margaret Kalcic, Rebecca Logsdon Muenich, Jennifer Read, Noel Aloysius, Isabella Bertani, Chelsie Boles, et al. 2017. "Multiple Models Guide Strategies for Agricultural Nutrient Reductions." Frontiers in Ecology and the Environment 15 (3): 126-132. https://doi.org/10.1002/fee.1472.

Shapiro, S. S., and M. B. Wilk. 1965. "An Analysis of Variance Test for Normality (Complete Samples).” Bimetrika 52 (3/4): 591-611. https://doi.org /10.2307/2333709.

Sharpley, Andrew N., Helen P. Jarvie, Anthony Buda, Linda May, Bryan Spears, and Peter Kleinman. 2013. "Phosphorus legacy: Overcoming the effects of Past Management Practices to Mitigate Future Water Quality Impairment.” Journal of Environmental Quality 42 (5): 1308-1326. https://doi.org/10.2134/jeq2013.03 .0098 . 
Sharpley, Andrew N., Tommy C. Daniel, George Gibson, Larry Bundy, Miguel Cabrera, Tom Sims, Robert Stevens, Jerry Lemunyon, Peter Kleinman, and Roberta Parry. 2006. Best Management Practices to Minimize Agricultural Phosphorus Impacts on Water Quality. USDA-ARS Publication 163. https://www.ars.usda.gov /research/publications/publication/?seqNo115 $=145857$

Slucher, E R, E M Swinford, G E Larsen, and D M Powers. 2006. Bedrock geologic map of Ohio: Ohio Division of Geological Survey Map BG-1, version 6.o, scale 1:50o,0oo. Columbus, OH: Ohio Department of Natural Resources.

Soil Survey Staff. 2020. United States Department of Agriculture 2020 Web Soil Survey. https://websoilsurvey.sc.egov.usda.gov/.

Stow, Craig A., YoonKyung Cha, Laura T. Johnson, Remegio Confesor, and R. Peter Richards. 2015. "Long-Term and Seasonal Trend Decomposition of Maumee River Nutrient Inputs to Western Lake Erie." Environmental Science and Technology 49 (6): 3392-3400. https://doi.org/10.1021/es5062648.

United States Army Corps of Engineers. 2010. Regional Supplement to the Corps of Engineers Wetland Delineation Manual: Midwest Region (Version 2.o). ERDC/EL TR-10-16. Vicksburg, MS: United States Army Engineer Research and Development Center. http://hdl.handle.net/11681/6941.

United States Environmental Protection Agency. 1994. "Method 200.7: Determination of Metals and Trace Elements in Water and Wastes by Inductively Coupled PlasmaAtomic Emission Spectrometry," Revision 4.4. Cincinnati, OH

United States Environmental Protection Agency. 2020. Great Lakes Restoration Initiative Action Plan III. Action Plan, United States Environmental Protection Agency. https://www.epa.gov/sites/production/files/2019-10/documents /glri-action-plan-3-201910-3opp.pdf.

VanZomeren, Christine M, Jacob F Berkowitz, A. Maria Lemke, and Krista G. Kirkham. 2019. "Soil P Storage Capacity in Agricultural Treatment Wetlands: Can a System Designed for N Reduction also Retain P?” Wetlands 40:503-514. https://doi.org /10.1007/s13157-019-01205-3.

Vasilas, Lenore M., and Jacob F Berkowitz. 2016. "Identifying hydric soils in the landscape." In Wetland Soils: Genesis, Hydrology, Landscapes, and Classification, 219-244. ISBN 9781439896983. CRC Press.

Vasilas, Lenore M., G. Wade Hurt, and Jacob F. Berkowitz. 2018. Field indicators of hydric soils in the United States: A Guide for Identifying and Delineating Hydric Soils, version 8.o. Guide, United States Department of Agriculture, 1-55. https://www.nrcs.usda.gov/Internet/FSE_DOCUMENTS/nrcs142p2_053171.pdf

Venteris, E. R., D. L. Shrake, G. E. Larson, M. P. Angle, and R. R. Pavey. 2008. Surficial Geology of Findlay 30 X 6o-Minute Quadrangle. SG-2 ed. Vol. 1:10o,ooo. Columbus, OH: Ohio Department of Natural Resources. 
Wang, N, and William J. Mitsch. 1998. "Estimating Phosphorus Retention of Existing and Restored Coastal Wetlands in a Tributary Watershed of the Laurentian Great Lakes in Michigan, USA." Wetlands Ecology and Management 6 (1): 69-82. https://doi.org/10.1023/A:1008451823394. 


\section{Appendix A: Soil Series and Geologic Data}

Soil Series Abbreviations, (\% slopes):

- $\mathrm{Pa}=$ Paulding clay, $0 \%-1 \%$

- $\mathrm{RsA}=$ Roselms silty clay, $\mathrm{o} \%-3 \%$

- $\mathrm{Pt}=$ Pits, quarry

- $\mathrm{SaS}_{3} \mathrm{AF}=$ Saranac-Spencerville silty clay loams, $0 \%-1 \%$, frequently flooded

- $\mathrm{Gn}=$ Genesee silt loam, $0 \%-2 \%$, occasionally flooded

- DeA = Del Rey silt loam, till substratum, $0 \%-3 \%$

- $\mathrm{TpA}=$ Toledo silty clay, $0 \%-1 \%$, flooded

- $\mathrm{NpA}=$ Nappanee silty clay loam, $0 \%-3 \%$

- $\mathrm{To}=$ Toledo silty clay, $\mathrm{o} \%-1 \%$

- $\mathrm{Tp}=$ Toledo silty clay, $\mathrm{o} \%-1 \%$, flooded

- $\mathrm{Rs}=$ Rossburg silt loam, occasionally flooded

- $\mathrm{MeB}=$ Mentor silt loam, $\mathbf{1} \%-4 \%$

- $\mathrm{Le}=$ Lenawee silty clay loam, $0 \%-1 \%$

- $\mathrm{Blg} 1 \mathrm{~A} 1=$ Blount silt loam, ground moraine, $1 \%-2 \%$

- $\mathrm{Ch}=$ Chagrin silt loam, occasionally flooded

- $\mathrm{Sh}=$ Shoals silt loam, $\mathrm{o} \%-2 \%$, frequently flooded

- $\mathrm{PmA}=$ Pewamo silty clay loam, $0 \%-1 \%$

Geology Descriptions:

- $\mathrm{Da}=$ Antrim Shale

- $\mathrm{Sl}=$ Lockport Dolomite

- $\mathrm{Oc}=$ Cincinnati group

- $\mathrm{O}=$ Organic Deposits, Holocene-Age

- $\mathrm{a}=$ Alluvium, Holocene-Age

- $\mathrm{C}=$ Clay, generally Wisconsinan-age

- $\mathrm{L}=$ Silt generally, Wisconsinan-age

- $\mathrm{T}=$ Till, undifferentiated in subsurface, unspecified age

- $\mathrm{TF}=$ Silty clay till, high carbonate content, Wisconsinan-age

- $\mathrm{SG}=$ Sand and Gravel, generally Wisconsinan-age

- $\mathrm{D}=$ Dolomite

- ( ) = patchy, discontinuous

- - = The number preceding is the thickest point and will thin out to the adjacent contour, unless there is not one, which would mean that it thins out until the edge of the labeled contour. 
- Numbers $=$ Average thickness of layer (number $\times 10 \mathrm{ft}$ ); for example, 4 is $40 \mathrm{ft}$, and 13 is $130 \mathrm{ft}$. No number generally assumes $10 \mathrm{ft}$ average thickness.

Table A-1. Soil series and surficial geology classification.

(Soil Survey Staff 2020; Pavey, et al. 2005; Venteris, et al. 2008; Larsen, Shrake and Swinford 2005; Slucher, et al. 2006.)

\begin{tabular}{|c|c|c|c|}
\hline Site name & Sample & Soil series & Geology \\
\hline City of Defiance & 21-1 & $\mathbf{P a}$ & Da \\
\hline City of Defiance & 21-2 & $\mathbf{P a}$ & Da \\
\hline City of Defiance & 21-3 & RsA & Da \\
\hline City of Defiance & 21-4 & $\mathbf{P a}$ & Da \\
\hline City of Defiance & $21-5$ & RsA & Da \\
\hline City of St. Marys & 30-3 & Blg1A1 & SI \\
\hline City of St. Marys & 30-4 & Pt & SI \\
\hline City of St. Marys & $30-5$ & SaS3AF & SI \\
\hline City of St. Marys & $30-6$ & SaS3AF & SI \\
\hline Auglaize County & 36-1 & Pt & SI \\
\hline Auglaize County & 36-2 & Blg1A1 & SI \\
\hline Auglaize County & 36-3 & Blg1A1 & SI \\
\hline Auglaize County & 36-4 & Pt & SI \\
\hline Auglaize County & $36-5$ & Pt & SI \\
\hline City of St. Marys & $37-1$ & Pt & Oc \\
\hline City of St. Marys & $37-4$ & Sh & Oc \\
\hline Private Owner St. Marys & $52-1$ & Sh & Oc \\
\hline Private Owner St. Marys & $52-2$ & Sh & Oc \\
\hline Private Owner St. Marys & $52-3$ & Blg1A1 & Oc \\
\hline Private Owner St. Marys & $52-4$ & Gn & Oc \\
\hline Private Owner St. Marys & $52-5$ & Blg1A1 & Oc \\
\hline Private Owner St. Marys & $52-6$ & Pt & Oc \\
\hline Private Owner St. Marys & 52-7 & Pt & Oc \\
\hline Private Owner St. Marys & $52-8$ & DeA & Oc \\
\hline Private Owner St. Marys & $52-9$ & DeA & Oc \\
\hline Standing Rush, LLC & 1 to 2 & Water & $\begin{array}{c}(\mathrm{O}) / \mathrm{C} 2 / \mathrm{L} 2 / \mathrm{T} 2 / \mathrm{D} \text { or sand gravel } \\
\text { pit }\end{array}$ \\
\hline Standing Rush, LLC & 3 to 6 & NpA & T2/D \\
\hline Standing Rush, LLC & 7 to 16 & TpA & $\begin{array}{c}(\mathrm{O}) / \mathrm{C} 2 / \mathrm{L} 2 / \mathrm{T} 2 / \mathrm{D} \text { or sand gravel } \\
\text { pit }\end{array}$ \\
\hline Maumee Bay State Park & 17 to 26 & To & C/TF13/D \\
\hline Ottawa National Wildlife Refuge & 27 to 37 & Tp & O/TF4/D \\
\hline
\end{tabular}




\begin{tabular}{cccc}
\hline Site name & Sample & Soil series & Geology \\
\hline Redhorse Bend & $\mathbf{3 8}$ to 39 & Tp & a/(L)/T4-/(SG)/D \\
\hline Redhorse Bend & $\mathbf{4 0}$ to 43 & Rs & a/(L)/T4-/(SG)/D \\
\hline Redhorse Bend & $\mathbf{4 4}$ to 47 & MeB & a/(L)/T4-/(SG)/D \\
\hline Fruth Outdoor Center & $\mathbf{4 8}$ to 49 & Le & (LC)/T5/D \\
\hline Fruth Outdoor Center & $\mathbf{5 0 ~ t o ~} 53$ & Blg1A1 & (LC)/T5/D \\
\hline Fruth Outdoor Center & $\mathbf{5 4 ~ t o ~ 5 5}$ & Le & (LC)/T5/D \\
\hline Fruth Outdoor Center & $\mathbf{5 6}$ to 57 & Blg1A1 & (LC)/T5/D \\
\hline Hecks Bridge & $\mathbf{5 8}$ to 61 & Ch & T16-/(SG2)/D \\
\hline Wolf Creek & $\mathbf{6 2 ~ t o ~} 65$ & $\mathbf{R s}$ & a/T/D \\
\hline Oakwoods Nature Preserve & $\mathbf{6 6}$ to 69 & Blg1A1 & T2/D \\
\hline Oakwoods Nature Preserve & $\mathbf{7 0 ~ t o ~} 79$ & PmA & (T)/D \\
\hline
\end{tabular}

Table A-2. Sample watersheds.

\begin{tabular}{|c|c|c|}
\hline Sample ID & County & Watershed \\
\hline 21 & Auglaize & Maumee \\
\hline 30 & St. Marys & Maumee \\
\hline 36 & Auglaize & Maumee \\
\hline 37 & St. Marys & Maumee \\
\hline 52 & St. Marys & Maumee \\
\hline Fruth Outdoor Center & Seneca & Sandusky \\
\hline Hecks Bridge & Seneca & Sandusky \\
\hline Maumee Bay state park & Lucas & Portage \\
\hline Oakwoods Nature Preserve & Hancock & Maumee \\
\hline Ottawa National Wildlife Refuge & Ottawa & Portage \\
\hline Redhorse Bend & Sandusky & Sandusky \\
\hline Standing Rush, LLC & Erie & Sandusky \\
\hline Wolf Creek & Sandusky & Sandusky \\
\hline
\end{tabular}




\section{Appendix B: Study Location Land Use}

Table B-1. Land use (PO = private owner).

\begin{tabular}{|c|c|c|}
\hline Site description & Sample & Land use \\
\hline Auglaize County & 36-1 & Row crop \\
\hline Auglaize County & $36-2$ & Row crop \\
\hline Auglaize County & 36-3 & Row crop \\
\hline Auglaize County & $36-4$ & Row crop \\
\hline Auglaize County & $36-5$ & Row crop \\
\hline City of Defiance & 21-1 & Row crop \\
\hline City of Defiance & 21-2 & Row crop \\
\hline City of Defiance & 21-3 & Row crop \\
\hline City of Defiance & 21-4 & Row crop \\
\hline City of Defiance & 21-5 & Row crop \\
\hline City of St. Marys & 30-3 & Row crop \\
\hline City of St. Marys & $30-4$ & Row crop \\
\hline City of St. Marys & $30-5$ & Row crop \\
\hline City of St. Marys & $30-6$ & Row crop \\
\hline City of St. Marys & 37-1 & Grass \\
\hline City of St. Marys & $37-4$ & Grass \\
\hline St. Marys (PO) & $52-1$ & Row crop \\
\hline St. Marys (PO) & $52-2$ & Row crop \\
\hline St. Marys (PO) & $52-3$ & Row crop \\
\hline St. Marys (PO) & $52-4$ & Row crop \\
\hline St. Marys (PO) & $52-5$ & Row crop \\
\hline St. Marys (PO) & $52-6$ & Row crop \\
\hline St. Marys (PO) & $52-7$ & Row crop \\
\hline St. Marys (PO) & $52-8$ & Row crop \\
\hline St. Marys (PO) & $52-9$ & Row crop \\
\hline Standing Rush, LLC & 1 & Marsh \\
\hline Standing Rush, LLC & 3 & Marsh \\
\hline Standing Rush, LLC & 7 & Marsh \\
\hline Standing Rush, LLC & 10 & Marsh \\
\hline Standing Rush, LLC & 14 & Marsh \\
\hline Maumee Bay State Park & 17 & Forested marsh \\
\hline Maumee Bay State Park & 19 & Forested marsh \\
\hline Maumee Bay State Park & 21 & Forested marsh \\
\hline Maumee Bay State Park & 23 & Marsh \\
\hline Maumee Bay State Park & 25 & Marsh \\
\hline
\end{tabular}




\begin{tabular}{|c|c|c|}
\hline Site description & Sample & Land use \\
\hline Ottawa National Wildlife Refuge & 27 & Marsh \\
\hline Ottawa National Wildlife Refuge & 30 & Marsh \\
\hline Ottawa National Wildlife Refuge & 33 & Marsh \\
\hline Ottawa National Wildlife Refuge & 34 & Marsh \\
\hline Ottawa National Wildlife Refuge & 36 & Marsh \\
\hline Redhorse Bend & 38 & Agricultural \\
\hline Redhorse Bend & 40 & Agricultural \\
\hline Redhorse Bend & 42 & Agricultural \\
\hline Redhorse Bend & 44 & Agricultural \\
\hline Redhorse Bend & 46 & Agricultural \\
\hline Fruth Outdoor Center & 48 & Emergent wetland \\
\hline Fruth Outdoor Center & 50 & Emergent wetland \\
\hline Fruth Outdoor Center & 52 & Recreational field \\
\hline Fruth Outdoor Center & 54 & Recreational field \\
\hline Fruth Outdoor Center & 56 & Forested wetland \\
\hline Hecks Bridge & 58 & Forested wetland \\
\hline Hecks Bridge & 60 & Forested wetland \\
\hline Wolf Creek & 62 & Forested wetland \\
\hline Wolf Creek & 64 & Forested wetland \\
\hline Oakwoods Nature Preserve & 66 & Agricultural \\
\hline Oakwoods Nature Preserve & 68 & Forested wetland \\
\hline Oakwoods Nature Preserve & 70 & Forested wetland \\
\hline Oakwoods Nature Preserve & 72 & Agricultural \\
\hline Oakwoods Nature Preserve & 74 & Agricultural \\
\hline Oakwoods Nature Preserve & 76 & Agricultural \\
\hline Oakwoods Nature Preserve & 78 & Agricultural \\
\hline
\end{tabular}




\section{Appendix C: Soil Data Summary}

Table C-1. Soil analytical data from section 2; all units are $\mathrm{mgkg}^{-1}$ except PSR, which is unitless. ( $\mathrm{S}=$ surface horizon, $\mathrm{SS}=$ subsurface horizon)

\begin{tabular}{|c|c|c|c|c|c|c|c|}
\hline \multirow[b]{2}{*}{ Sample } & \multirow[b]{2}{*}{ Soil horizon } & \multicolumn{3}{|c|}{ Nutrients } & \multirow{2}{*}{$\begin{array}{l}\text { Soil P saturation } \\
\text { ratio (M1) }\end{array}$} & \multirow{2}{*}{$\begin{array}{l}\text { Capacity } \\
\text { factor }\end{array}$} & \multirow{2}{*}{$\begin{array}{c}\text { Water-soluble } \mathrm{P} \\
(\mathrm{mgP} / \mathrm{kg})\end{array}$} \\
\hline & & $\mathrm{P}$ & $\mathrm{Fe}$ & $\mathrm{Al}$ & & & \\
\hline $21-1$ & $\mathrm{~S}$ & 0.344 & 7.792 & 0.92 & 0.064063 & 0.193 & 0.96 \\
\hline $21-1$ & SS1 & 0.732 & 2.36 & 153.41 & 0.004125 & 17.0131 & 0.98 \\
\hline $21-2$ & $\mathrm{~S}$ & 1.744 & 3.812 & 30.604 & 0.046821 & 1.9808 & 1.57 \\
\hline $21-2$ & SS1 & 1.34 & 59.708 & 378.36 & 0.002867 & 45.4066 & 0.22 \\
\hline $21-3$ & $\mathrm{~S}$ & 2.74 & 55.572 & 367.08 & 0.006059 & 42.4825 & 0.21 \\
\hline $21-3$ & SS1 & 1.452 & 61.528 & 358.8 & 0.003255 & 43.1496 & 0.34 \\
\hline $21-4$ & $\mathrm{~S}$ & 7.092 & 80.168 & 228.08 & 0.023158 & 23.5328 & 0.58 \\
\hline $21-4$ & SS1 & 5.092 & 108.516 & 273.52 & 0.013611 & 32.3193 & 0.26 \\
\hline $21-5$ & $\mathrm{~S}$ & 0.208 & 0.788 & 11.98 & 0.014657 & 1.2111 & 0.63 \\
\hline $21-5$ & SS1 & 0.048 & 0.376 & 0.432 & 0.068168 & 0.0224 & 0.27 \\
\hline $30-3$ & $\mathrm{~S}$ & 35.704 & 19.992 & 208.04 & 0.142857 & -10.7112 & 6.14 \\
\hline $30-3$ & SS1 & 11.204 & 21.828 & 196.96 & 0.047032 & 12.6183 & 1.3 \\
\hline $30-4$ & $\mathrm{~S}$ & 35.004 & 4.04 & 115.96 & 0.258569 & -21.4664 & 5.76 \\
\hline $30-4$ & SS1 & 5.164 & 27.812 & 222.6 & 0.019057 & 21.9334 & 1.09 \\
\hline $30-5$ & $\mathrm{~S}$ & 42.86 & 9.376 & 197.76 & 0.184544 & -19.6352 & 3.93 \\
\hline $30-5$ & SS1 & 18.416 & 23.196 & 209.24 & 0.072768 & 6.8919 & 1.35 \\
\hline $30-6$ & $\mathrm{~S}$ & 47.148 & 5.02 & 177.88 & 0.227755 & -26.4468 & 5.75 \\
\hline $30-6$ & SS1 & 16.968 & 7.12 & 172.28 & 0.084106 & 3.2064 & 7.23 \\
\hline $36-1$ & SS1 & 19.388 & 17.72 & 183.4 & 0.087975 & 2.65 & 1.23 \\
\hline $36-1$ & $\mathrm{~S}$ & 42.464 & 21.72 & 218.32 & 0.161652 & -16.1953 & 1.19 \\
\hline $36-2$ & S & 9.744 & 31.512 & 190.44 & 0.041271 & 13.8657 & 0.64 \\
\hline $36-2$ & SS1 & 4.532 & 52.304 & 195.84 & 0.017856 & 20.8487 & 3.2 \\
\hline $36-3$ & $\mathrm{~S}$ & 12.436 & 21.096 & 185.08 & 0.055474 & 9.9817 & 1.1 \\
\hline $36-3$ & SS1 & 2.488 & 39.2 & 150.56 & 0.012787 & 16.9685 & 0.28 \\
\hline $36-4$ & $\mathrm{~S}$ & 29.356 & 10.444 & 215.68 & 0.115842 & -4.0146 & 2.34 \\
\hline $36-4$ & SS1 & 17.756 & 12.792 & 228.6 & 0.065873 & 9.1988 & 0.71 \\
\hline $36-5$ & $\mathrm{~S}$ & 827.31 & 98.996 & 422.76 & 1.531521 & -773.297 & 130.06 \\
\hline $36-5$ & SS1 & 76.448 & 36.532 & 213.52 & 0.288075 & -49.9104 & 1.33 \\
\hline $37-1$ & $\mathrm{~S}$ & 1.236 & 2.232 & 1.42 & 0.431272 & -0.9494 & 7.55 \\
\hline $37-1$ & SS1 & 0.112 & 0.46 & 1.368 & 0.061359 & 0.0705 & 0.56 \\
\hline $37-1$ & SS2 & 0.116 & 0.356 & 7.76 & 0.012738 & 0.7947 & 0.33 \\
\hline $37-4$ & $\mathrm{~S}$ & 11.56 & 2.76 & 779.7 & 0.012891 & 78.1139 & 6.92 \\
\hline $37-4$ & SS1 & 0.472 & 0.204 & 13.92 & 0.029326 & 1.1375 & 0.71 \\
\hline $52-1$ & $\mathrm{~S}$ & 64.54 & 6.628 & 200.52 & 0.275935 & -41.1504 & 6.53 \\
\hline $52-1$ & SS1 & 7.872 & 3.328 & 225.48 & 0.030193 & 18.2007 & 0.49 \\
\hline $52-2$ & $\mathrm{~S}$ & 6.772 & 1.504 & 10.892 & 0.507715 & -5.4382 & 5.98 \\
\hline $52-2$ & SS1 & 4.32 & 4.988 & 75.44 & 0.048334 & 4.6178 & 1.12 \\
\hline
\end{tabular}




$\begin{array}{lccccccc}52-3 & \mathrm{~S} & \mathbf{4 3 . 5 8 8} & \mathbf{8 . 8 3 2} & \mathbf{2 0 6 . 8 4} & \mathbf{0 . 1 7 9 8 3 9} & \mathbf{- 1 9 . 3 5 0 8} & \mathbf{2 . 7 8} \\ 52-3 & \mathrm{~S} 1 & \mathbf{0 . 3 4 8} & \mathbf{0 . 2 2 8} & \mathbf{1 6 . 4 0 8} & \mathbf{0 . 0 1 8 3 5} & \mathbf{1 . 5 4 8 5} & \mathbf{0 . 1 7} \\ 52-4 & \mathrm{~S} & \mathbf{6 5 . 2 6} & \mathbf{1 . 6 6} & \mathbf{7 3 . 3 6} & \mathbf{0 . 7 6 6 4 3 9} & \mathbf{- 5 6 . 7 4 5 3} & \mathbf{1 2 . 6 2} \\ 52-4 & \mathrm{~S} 1 & \mathbf{1 7 . 7 6 8} & \mathbf{1 . 2 4} & \mathbf{1 0 5} & \mathbf{0 . 1 4 6 5 5} & \mathbf{- 5 . 6 4 3 8} & \mathbf{1 . 9 2} \\ 52-5 & \mathrm{~S} & \mathbf{5 0 . 2 8 4} & \mathbf{4 . 3 6} & \mathbf{1 4 8 . 3 2} & \mathbf{0 . 2 9 1 1 5 2} & \mathbf{- 3 3 . 0 1 3 3} & \mathbf{3 . 1 8} \\ 52-5 & \mathrm{~S} S & \mathbf{0 . 0 2 4} & \mathbf{0 . 4 6} & \mathbf{0 . 4 2} & \mathbf{0 . 0 3 2 5 7} & \mathbf{0 . 0 4 9 7} & \mathbf{0 . 3 9} \\ 52-6 & \mathrm{~S} & \mathbf{1 1 . 0 3 2} & \mathbf{2 . 5 4 4} & \mathbf{3 5 . 1 2 8} & \mathbf{0 . 2 6 4 3} & \mathbf{- 6 . 8 5 8} & \mathbf{6 . 5 4} \\ 52-6 & \mathrm{~S} 1 & \mathbf{1 0 . 3 6 4} & \mathbf{9 . 7 7 2} & \mathbf{1 9 5 . 8 4} & \mathbf{0 . 0 4 5 0 0 9} & \mathbf{1 2 . 6 6 2 3} & \mathbf{0 . 5 9} \\ 52-7 & \mathrm{~S} & \mathbf{1 2 . 0 3 2} & \mathbf{1 3 . 6 9 2} & \mathbf{5 5 . 0 2} & \mathbf{0 . 1 7 0 0 6 2} & \mathbf{- 4 . 9 5 6 9} & \mathbf{6 . 2 6} \\ 52-7 & \mathrm{~S} 1 & \mathbf{1 . 7 2 4} & \mathbf{1 5 . 8 9 6} & \mathbf{1 7 3 . 6 8} & \mathbf{0 . 0 0 8 2 8} & \mathbf{1 9 . 0 9 7} & \mathbf{0 . 5 8} \\ 52-8 & \mathrm{~S} & \mathbf{1 5 . 1 5 6} & \mathbf{5 . 4 9 6} & \mathbf{1 8 7 . 6 8} & \mathbf{0 . 0 6 9 3 5 5} & \mathbf{6 . 6 9 6 7} & \mathbf{1 . 2 8} \\ 52-8 & \mathrm{~S} 1 & \mathbf{3 . 3 1 6} & \mathbf{1 3 . 4 9 2} & \mathbf{2 3 1 . 4} & \mathbf{0 . 0 1 2 1 4} & \mathbf{2 3 . 9 9 9} & \mathbf{0 . 5 8} \\ 52-9 & \mathrm{~S} & \mathbf{5 . 1 4 8} & \mathbf{1 . 2 7 6} & \mathbf{4 8 . 8} & \mathbf{0 . 0 9 0 7 3 6} & \mathbf{0 . 5 2 5 6} & \mathbf{2 . 2 4} \\ 52-9 & \mathrm{~S} 1 & \mathbf{1 . 4 7 6} & \mathbf{3 6 . 5 4} & \mathbf{2 5 1 . 7 2} & \mathbf{0 . 0 0 4 7 7 3} & \mathbf{2 9 . 4 4 7 9} & \mathbf{0 . 5 6}\end{array}$

Table C-2. Soil analytical data from section 3; all units are $\mathrm{mgkg}^{-1}$ except PSR, which is unitless. ( $\mathrm{S}$ = surface horizon; $\mathrm{SS}=$ subsurface horizon.)

\begin{tabular}{|c|c|c|c|c|c|c|c|}
\hline \multirow[t]{2}{*}{ Sample } & \multirow{2}{*}{$\begin{array}{l}\text { Soil } \\
\text { horizon }\end{array}$} & \multicolumn{3}{|c|}{ Nutrients } & \multirow{2}{*}{$\begin{array}{l}\text { Soil } \mathrm{P} \\
\text { saturation } \\
\text { ratio (M3) }\end{array}$} & \multirow{2}{*}{$\begin{array}{l}\text { Capacity } \\
\text { factor }\end{array}$} & \multirow{2}{*}{$\begin{array}{l}\text { Water } \\
\text { Soluble P } \\
(\mathrm{mg}-\mathrm{P} / \mathrm{kg})\end{array}$} \\
\hline & & $\mathrm{P}$ & $\mathrm{Fe}$ & $\mathrm{Al}$ & & & \\
\hline Standing Rush 1 & $\mathbf{S}$ & 11.07 & 76.3 & 37.7 & 0.1294 & -10.21 & 1.07 \\
\hline Standing Rush 2 & SS1 & 57.24 & 190 & 140 & 0.2153 & -54.58 & 1.2 \\
\hline Standing Rush 3 & $\mathbf{S}$ & 7.44 & 72.3 & 30.3 & 0.0994 & -6.69 & 1.04 \\
\hline Standing Rush 4 & SS1 & 8.94 & 125 & 65.1 & 0.0621 & -7.50 & 0.78 \\
\hline Standing Rush 5 & SS2 & 6.55 & 456 & 252 & 0.0121 & -1.13 & 0.68 \\
\hline Standing Rush 6 & SS3 & $\mathbf{0}$ & 208 & 2.12 & 0.0000 & 1.18 & $\mathbf{0}$ \\
\hline Standing Rush 7 & $\mathbf{S}$ & 5.22 & 46.5 & 17 & 0.1153 & -4.77 & 1.06 \\
\hline Standing Rush 8 & SS1 & 10.74 & 72.5 & 30.1 & 0.1438 & -9.99 & 1.05 \\
\hline Standing Rush 9 & SS2 & 2.39 & 39.9 & 3.92 & 0.0899 & -2.12 & 0.76 \\
\hline Standing Rush 10 & $\mathbf{S}$ & 8.52 & 94 & 38.6 & 0.0884 & -7.56 & 1.09 \\
\hline Standing Rush 11 & SS1 & 7.27 & 132 & 45.4 & 0.0581 & -6.02 & 0.65 \\
\hline Standing Rush 12 & SS2 & $\mathbf{0}$ & 66.7 & 7.51 & 0.0000 & 0.46 & 0 \\
\hline Standing Rush 13 & SS3 & 1.66 & 187 & 44.6 & 0.0107 & -0.11 & $\mathbf{0}$ \\
\hline Standing Rush 14 & $\mathbf{S}$ & 10.79 & 252 & 99.6 & 0.0425 & -8.25 & 1 \\
\hline Standing Rush 15 & SS1 & 3.17 & 313 & 155 & 0.0090 & 0.34 & $\mathbf{0}$ \\
\hline Standing Rush 16 & SS2 & $\mathbf{0}$ & 75.7 & 9.19 & 0.0000 & 0.52 & $\mathbf{0}$ \\
\hline Maumee Bay 17 & $\mathbf{S}$ & 8.63 & 590 & 862 & 0.0066 & 4.53 & 0.96 \\
\hline Maumee Bay 18 & SS1 & 11.37 & 571 & 898 & 0.0084 & 2.10 & 0.94 \\
\hline Maumee Bay 19 & $\mathbf{S}$ & 31.78 & 569 & 756 & 0.0269 & -19.95 & 1.95 \\
\hline
\end{tabular}




\begin{tabular}{|c|c|c|c|c|c|c|c|}
\hline \multirow[t]{2}{*}{ Sample } & \multirow{2}{*}{$\begin{array}{l}\text { Soil } \\
\text { horizon }\end{array}$} & \multicolumn{3}{|c|}{ Nutrients } & \multirow{2}{*}{$\begin{array}{l}\text { Soil } P \\
\text { saturation } \\
\text { ratio (M3) }\end{array}$} & \multirow{2}{*}{$\begin{array}{l}\text { Capacity } \\
\text { factor }\end{array}$} & \multirow{2}{*}{$\begin{array}{l}\text { Water } \\
\text { Soluble P } \\
(\mathrm{mg}-\mathrm{P} / \mathrm{kg})\end{array}$} \\
\hline & & $\mathrm{P}$ & $\mathrm{Fe}$ & $\mathrm{Al}$ & & & \\
\hline Maumee Bay 20 & SS1 & 13.19 & 511 & 782 & 0.0112 & -1.38 & 0.95 \\
\hline Maumee Bay 21 & $\mathbf{S}$ & 15.32 & 621 & 898 & 0.0111 & -1.57 & 1.52 \\
\hline Maumee Bay 22 & SS1 & 7.78 & 640 & 1010 & 0.0051 & 7.36 & 1.07 \\
\hline Maumee Bay 23 & $\mathbf{S}$ & 17.28 & 618 & 880 & 0.0128 & -3.76 & 1.51 \\
\hline Maumee Bay 24 & SS1 & 8.63 & 638 & 919 & 0.0061 & 5.45 & 1.37 \\
\hline Maumee Bay 25 & $\mathbf{S}$ & 6.64 & 582 & 1080 & 0.0043 & 8.98 & 1.33 \\
\hline Maumee Bay 26 & SS1 & 4.12 & 600 & 1050 & 0.0027 & 11.26 & 0.86 \\
\hline Ottawa Large 27 & $\mathbf{S}$ & 7.47 & 554 & 720 & 0.0066 & 3.86 & 0.61 \\
\hline Ottawa Large 28 & SS1 & 4.9 & 570 & 738 & 0.0042 & 6.73 & 0.71 \\
\hline Ottawa Large 29 & SS2 & 8.52 & 560 & 898 & 0.0064 & 4.89 & 0.64 \\
\hline Ottawa Large 30 & $\mathbf{S}$ & 4.42 & 571 & 893 & 0.0033 & 8.99 & 1.08 \\
\hline Ottawa 2B 31 & SS1 & 7.9 & 572 & 700 & 0.0071 & 3.30 & 0.9 \\
\hline Ottawa 2B 32 & SS2 & 6.14 & 544 & 875 & 0.0047 & 6.92 & 0.84 \\
\hline Ottawa 2B 33 & $\mathbf{S}$ & 7.42 & 639 & 855 & 0.0056 & 5.93 & 1.15 \\
\hline Ottawa 2A 34 & $\mathbf{S}$ & 13.04 & 563 & 863 & 0.0100 & -0.01 & 1.14 \\
\hline Ottawa 2A 35 & SS1 & 4.77 & 593 & 1090 & 0.0030 & 11.03 & 0.82 \\
\hline Ottawa 2A 36 & $\mathbf{S}$ & 1.07 & 695 & 840 & 0.0008 & 12.42 & 0.78 \\
\hline Ottawa 2A 37 & SS1 & 1.31 & 657 & 1040 & 0.0008 & 14.27 & 0.83 \\
\hline Red horse Tp 38 & $\mathbf{S}$ & 104.38 & 561 & 781 & 0.0865 & -92.31 & 4.79 \\
\hline Red horse Tp 39 & SS1 & 44.46 & 397 & 683 & 0.0443 & -34.42 & 1.83 \\
\hline Red horse RS 40 & $\mathbf{S}$ & 117 & 526 & 791 & 0.0976 & -105.01 & 5.63 \\
\hline Red horse RS 41 & SS1 & 38.14 & 499 & 787 & 0.0323 & -26.34 & 1.58 \\
\hline Red horse RS 42 & $\mathbf{S}$ & 30.42 & 427 & 650 & 0.0310 & -20.59 & 1.53 \\
\hline Red horse RS 43 & SS1 & 21.96 & 402 & 748 & 0.0203 & -11.15 & 1.52 \\
\hline Red horse MeB 44 & $\mathbf{S}$ & 47.28 & 459 & 983 & 0.0342 & -33.45 & 2.85 \\
\hline Red horse MeB 45 & SS1 & 36.9 & 490 & 1140 & 0.0234 & -21.10 & 1.42 \\
\hline Red horse MeB 46 & $\mathbf{S}$ & 49.93 & 527 & 1220 & 0.0295 & -33.01 & 1.51 \\
\hline Red horse MeB 47 & SS1 & 36.45 & 478 & 1340 & 0.0202 & -18.42 & 1.34 \\
\hline YMCA 48 & $\mathbf{S}$ & 32.11 & 566 & 1250 & 0.0184 & -14.62 & 1.93 \\
\hline YMCA 49 & SS1 & 26.54 & 543 & 1130 & 0.0166 & -10.56 & 1.67 \\
\hline YMCA 50 & $\mathbf{S}$ & 4.01 & 599 & 1140 & 0.0024 & 12.39 & 1.01 \\
\hline YMCA 51 & SS1 & 21.5 & 563 & 1040 & 0.0143 & -6.44 & 1.21 \\
\hline YMCA 52 & $\mathbf{S}$ & 14.7 & 424 & 1010 & 0.0105 & -0.76 & 0.86 \\
\hline YMCA 53 & SS1 & 0.91 & 334 & 1090 & 0.0006 & 13.45 & 0.58 \\
\hline YMCA 54 & $\mathbf{S}$ & 8.39 & 357 & 895 & 0.0068 & 3.86 & 0.84 \\
\hline YMCA 55 & SS1 & $\mathbf{0}$ & 357 & 1040 & 0.0000 & 13.92 & 0 \\
\hline
\end{tabular}




\begin{tabular}{|c|c|c|c|c|c|c|c|}
\hline \multirow[t]{2}{*}{ Sample } & \multirow{2}{*}{$\begin{array}{l}\text { Soil } \\
\text { horizon }\end{array}$} & \multicolumn{3}{|c|}{ Nutrients } & \multirow{2}{*}{$\begin{array}{l}\text { Soil } P \\
\text { saturation } \\
\text { ratio (M3) }\end{array}$} & \multirow{2}{*}{$\begin{array}{l}\text { Capacity } \\
\text { factor }\end{array}$} & \multirow{2}{*}{$\begin{array}{l}\text { Water } \\
\text { Soluble P } \\
(\mathrm{mg}-\mathrm{P} / \mathrm{kg})\end{array}$} \\
\hline & & $\mathrm{P}$ & $\mathrm{Fe}$ & $\mathrm{Al}$ & & & \\
\hline YMCA 56 & $\mathbf{S}$ & 11.35 & 513 & 794 & 0.0095 & 0.61 & 2.28 \\
\hline YMCA 57 & SS1 & 2.24 & 504 & 1090 & 0.0015 & 13.06 & 0.76 \\
\hline Heck Bridge 58 & $\mathbf{S}$ & 11.51 & 555 & 989 & 0.0080 & 2.92 & 1.12 \\
\hline Heck Bridge 59 & SS1 & 1.89 & 458 & 949 & 0.0014 & 11.54 & 1.1 \\
\hline Heck Bridge 60 & $\mathbf{S}$ & 7.35 & 567 & 1070 & 0.0048 & 8.07 & 0.99 \\
\hline Heck Bridge 61 & SS1 & 0.98 & 489 & 936 & 0.0007 & 12.47 & 1.67 \\
\hline Wolf Creek 62 & $\mathbf{S}$ & 14.47 & 570 & 1040 & 0.0096 & 0.63 & 1.5 \\
\hline Wolf Creek 63 & SS1 & 8.27 & 485 & 1020 & 0.0057 & 6.13 & 0.93 \\
\hline Wolf Creek 64 & $\mathbf{S}$ & 24.48 & 550 & 913 & 0.0181 & -10.95 & 1.94 \\
\hline Wolf Creek 65 & SS1 & 13 & 504 & 999 & 0.0091 & 1.26 & 1.3 \\
\hline Hancock County 66 & $\mathbf{S}$ & 12.7 & 376 & 1290 & 0.0075 & 4.19 & 0.66 \\
\hline Hancock County 67 & SS1 & 2.75 & 393 & 1320 & 0.0016 & 14.58 & 1.33 \\
\hline Hancock County 68 & $\mathbf{S}$ & 3.67 & 275 & 743 & 0.0037 & 6.38 & 1.82 \\
\hline Hancock County 69 & SS1 & $\mathbf{0}$ & 301 & 984 & 0.0000 & 12.96 & $\mathbf{0}$ \\
\hline Hancock County 70 & $\mathbf{S}$ & 8.07 & 549 & 811 & 0.0065 & 4.28 & 1.72 \\
\hline Hancock County 71 & SS1 & $\mathbf{0}$ & 372 & 969 & 0.0000 & 13.18 & 0.74 \\
\hline Hancock County 72 & $\mathbf{S}$ & 29.19 & 469 & 1160 & 0.0183 & -13.28 & 1.5 \\
\hline Hancock County 73 & SS1 & 10.25 & 473 & 1180 & 0.0063 & 5.92 & 0.9 \\
\hline Hancock County 74 & $\mathbf{S}$ & $\mathbf{0}$ & 495 & 1040 & 0.0000 & 14.68 & 4.73 \\
\hline Hancock County 75 & SS1 & 23.96 & 433 & 1030 & 0.0168 & -9.74 & 2.33 \\
\hline Hancock County 76 & $\mathbf{S}$ & 36.82 & 535 & 1180 & 0.0223 & -20.31 & 1.64 \\
\hline Hancock County 77 & SS1 & 1.22 & 380 & 1180 & 0.0008 & 14.43 & 0.72 \\
\hline Hancock County 78 & $\mathbf{S}$ & 43.95 & 462 & 1150 & 0.0279 & -28.19 & 1.97 \\
\hline Hancock County 79 & SS1 & 4.8 & 372 & 1150 & 0.0031 & 10.46 & 0.76 \\
\hline
\end{tabular}




\section{Appendix D: Soil Series Descriptions}

Blg1A1-Blount silt loam, ground moraine, $0 \%-2 \%$ slopes

Map Unit Setting

National map unit symbol: $2 \mathrm{skcv}$

Elevation: $700-1,300 \mathrm{ft}$

Mean annual precipitation: $34-42$ in

Mean annual air temperature: $48-54^{\circ} \mathrm{F}$

Frost-free period: $140-180 \mathrm{~d}$

Farmland classification: Prime farmland if drained

Map Unit Composition

Blount, ground moraine, and similar soils: $85 \%$

Minor components: $15 \%$

Estimates are based on observations, descriptions, and transects of the map unit.

Description of Blount, Ground Moraine

Setting

Landform: Ground moraines on till plains

Landform position (two-dimensional): Footslope

Landform position (three-dimensional): Interfluve

Down-slope shape: Linear

Across-slope shape: Linear

Parent material: Wisconsin till derived from limestone and shale

Typical profile

Ap- $0-10$ in: silt loam

$\mathrm{Bt}-10-33$ in: silty clay

BC-33-39 in: clay loam

Cd-39-79 in: clay loam

Properties and qualities

Slope: $0 \%-2 \%$

Depth to restrictive feature: $31-54$ in to densic material

Natural drainage class: Somewhat poorly drained

Runoff class: High

Capacity of the most limiting layer to transmit water (Ksat): Low to moderately high

$(0.01-0.20 \mathrm{in} / \mathrm{hr})$

Depth to water table: About 6-12 in

Frequency of flooding: None

Frequency of ponding: None

Calcium carbonate, maximum in profile: $35 \%$

Salinity, maximum in profile: Nonsaline to very slightly saline $(0.0-2.0 \mathrm{mmhos} / \mathrm{cm})$

Available water storage in profile: Moderate (about 6.2 in)

Interpretive groups

Land capability classification (irrigated): None specified

Land capability classification (nonirrigated): $2 \mathrm{w}$

Hydrologic Soil Group: D

Minor Components

Hydric soil rating: No

Pewamo, ground moraine

Percent of map unit: $9 \%$

Landform: Ground moraines on till plains

Landform position (two-dimensional): Toeslope

Landform position (three-dimensional): Base slope

Down-slope shape: Linear

Across-slope shape: Concave, linear

Hydric soil rating: Yes

Glynwood, ground moraine 
Percent of map unit: $6 \%$

Landform: Ground moraines on till plains

Landform position (two-dimensional): Shoulder, backslope

Landform position (three-dimensional): Side slope, nose slope

Down-slope shape: Convex

Across-slope shape: Linear

Hydric soil rating: No

\section{Ch-Chagrin silt loam, occasionally flooded}

Map Unit Setting

National map unit symbol: $5 \mathrm{pvx}$

Elevation: $640-1,040 \mathrm{ft}$

Mean annual precipitation: $32-42$ in

Mean annual air temperature: $48^{\circ} \mathrm{F}-55^{\circ} \mathrm{F}$

Frost-free period: $133-182 \mathrm{~d}$

Farmland classification: All areas are prime farmland

\section{Map Unit Composition}

Chagrin and similar soils: $85 \%$

Minor components: $15 \%$

Estimates are based on observations, descriptions, and transects of the map unit.

Description of Chagrin

Setting

Landform: Flood plains

Down-slope shape: Linear

Across-slope shape: Linear

Parent material: Alluvium

Typical profile

H1 $-0-9$ in: silt loam

H2-9-28 in: silt loam

H3-28-60 in: stratified fine sand to silt loam

Properties and qualities

Slope: $0 \%-2 \%$

Depth to restrictive feature: More than 80 in

Natural drainage class: Well drained

Runoff class: Low

Capacity of the most limiting layer to transmit water (Ksat): Moderately high to high

$(0.60-2.00 \mathrm{in} / \mathrm{hr})$

Depth to water table: About $48-72$ in

Frequency of flooding: Occasional

Frequency of ponding: None

Available water storage in profile: High (about 9.7 in)

Interpretive groups

Land capability classification (irrigated): None specified

Land capability classification (nonirrigated): $2 \mathrm{w}$

Hydrologic Soil Group: B

Hydric soil rating: No

Minor Components

Shoals

Percent of map unit: $12 \%$

Landform: Flood plains

Bedrock at 20-40 in

Percent of map unit: $3 \%$ 


\section{Le-Lenawee silty clay loam, $0 \%-1 \%$ slopes}

Map Unit Setting

National map unit symbol: 2wcf7

Elevation: $560-980 \mathrm{ft}$

Mean annual precipitation: $28-38$ in

Mean annual air temperature: $45-52^{\circ} \mathrm{F}$

Frost-free period: 135-230 days

Farmland classification: Prime farmland if drained

\section{Map Unit Composition}

Lenawee and similar soils: $93 \%$

Minor components: 7\%

Estimates are based on observations, descriptions, and transects of the map unit.

\section{Description of Lenawee}

Setting

Landform: Lakebeds (relict)

Down-slope shape: Linear

Across-slope shape: Linear

Parent material: Clayey glaciolacustrine deposits

Typical profile

Ap- $0-9$ in: silty clay loam

$\mathrm{Bg}-9-39$ in: silty clay loam

$\mathrm{Cg}-39-80$ in: silty clay loam

Properties and qualities

Slope: $0 \%-1 \%$

Depth to restrictive feature: More than 80 in

Natural drainage class: Poorly drained

Runoff class: Negligible

Capacity of the most limiting layer to transmit water (Ksat): Very low to low $(0.00-0.01$

in/hr)

Depth to water table: About 0 in

Frequency of flooding: None

Frequency of ponding: Frequent

Calcium carbonate, maximum in profile: $21 \%$

Salinity, maximum in profile: Non-saline $(0.0-0.6 \mathrm{mmhos} / \mathrm{cm})$

Available water storage in profile: Moderate (about 7.0 in)

Interpretive groups

Land capability classification (irrigated): None specified

Land capability classification (nonirrigated): $2 \mathrm{w}$

Hydrologic Soil Group: D

Ecological site: Wet Lake Plain Flats (F099XY013MI)

Minor Components

Hydric soil rating: Yes

Del rey

Percent of map unit: 7\%

Landform: Lakebeds (relict)

Microfeatures of landform position: Rises

Down-slope shape: Linear

Across-slope shape: Linear, convex

Hydric soil rating: No

MeB-Mentor silt loam, $1 \%-4 \%$ slopes

Map Unit Setting

National map unit symbol: $5 \mathrm{pg} 0$

Elevation: $580-1,200 \mathrm{ft}$

Mean annual precipitation: $27-40$ in 
Mean annual air temperature: $45^{\circ} \mathrm{F}-54^{\circ} \mathrm{F}$

Frost-free period: $140-195$ days

Farmland classification: All areas are prime farmland

\section{Map Unit Composition}

Mentor and similar soils: $85 \%$

Minor components: $15 \%$

Estimates are based on observations, descriptions, and transects of the map unit.

Description of Mentor

Setting

Landform: Outwash plains, lake plains, terraces

Parent material: Glaciolacustrine deposits

Typical profile

$\mathrm{H} 1-0-10$ in: silt loam

H2-10-53 in: silt loam

H3-53-60 in: stratified silty clay loam to sandy loam

Properties and qualities

Slope: $1 \%-4 \%$

Depth to restrictive feature: More than 80 in

Natural drainage class: Well drained

Runoff class: Low

Capacity of the most limiting layer to transmit water (Ksat): Moderately high to high

$(0.60-2.00 \mathrm{in} / \mathrm{hr})$

Depth to water table: About 48-72 in

Frequency of flooding: None

Frequency of ponding: None

Calcium carbonate, maximum in profile: $5 \%$

Available water storage in profile: High (about 11.4 in)

Interpretive groups

Land capability classification (irrigated): None specified

Land capability classification (nonirrigated): $2 \mathrm{e}$

Hydrologic Soil Group: B

Ecological site: Lake Plain Flats (F099XY007MI)

Hydric soil rating: No

Minor Components

Glynwood

Percent of map unit: 5\%

Landform: End moraines, ground moraines

Saylesville

Percent of map unit: $5 \%$

Landform: Lake plains

Landform position (two-dimensional): Back slope

Landform position (three-dimensional): Side slope

Down-slope shape: Linear

Colwood

Across-slope shape: Linear

Percent of map unit: 5\%

Landform: Drainage ways on terraces, drainage ways on outwash plains, drainage ways on lake plains, depressions on terraces, depressions on outwash plains, depressions on lake plains

Hydric soil rating: Yes

\section{NpA-Nappanee silty clay loam, $0 \%-3 \%$ slopes}

\section{Map Unit Setting}

National map unit symbol: 5q9q

Elevation: $600-800 \mathrm{ft}$ 
Mean annual precipitation: $27-36$ in

Mean annual air temperature: $45^{\circ} \mathrm{F}-52^{\circ} \mathrm{F}$

Frost-free period: $140-170 \mathrm{~d}$

Farmland classification: Prime farmland if drained

Map Unit Composition

Nappanee and similar soils: $85 \%$

Minor components: $15 \%$

Estimates are based on observations, descriptions, and transects of the map unit.

Description of Nappanee

Setting

Landform: Lake plains

Landform position (two-dimensional): Summit, shoulder

Landform position (three-dimensional): Rise

Down-slope shape: Linear

Across-slope shape: Linear

Parent material: Till

Typical profile

H1 $-0-8$ in: silty clay loam

H2 - 8-34 in: silty clay

H3-34-60 in: silty clay

Properties and qualities

Slope: $0 \%-3 \%$

Depth to restrictive feature: More than 80 in

Natural drainage class: Somewhat poorly drained

Runoff class: High

Capacity of the most limiting layer to transmit water (Ksat): Moderately low to

moderately high $(0.06-0.20 \mathrm{in} / \mathrm{hr})$

Depth to water table: About 12-24 in

Frequency of flooding: None

Frequency of ponding: None

Calcium carbonate, maximum in profile: $20 \%$

Available water storage in profile: Moderate (about 6.8 in)

Interpretive groups

Land capability classification (irrigated): None specified

Land capability classification (nonirrigated): $3 \mathrm{w}$

Hydrologic Soil Group: C/D

Ecological site: Lake Plain Flats (F099XY007MI)

Forage suitability group: Unnamed (G099XY000OH)

Hydric soil rating: No

Minor Components

Lenawee

Percent of map unit: $3 \%$

Landform: Depressions, flats, drainage ways

Hydric soil rating: Yes

Latty

Percent of map unit: $3 \%$

Landform: Depressions, flats, drainage ways

Hoytville

Hydric soil rating: Yes

Percent of map unit: 3\%

Landform: Depressions, drainage ways, flats

Toledo

Hydric soil rating: Yes

Percent of map unit: $3 \%$

Landform: Depressions, flats, drainage ways

Hydric soil rating: Yes 
St. Clair

Percent of map unit: $3 \%$

Landform: End moraines, lake plains, ground moraines

Landform position (two-dimensional): Summit, shoulder, back slope

Landform position (three-dimensional): Side slope

Down-slope shape: Linear

Across-slope shape: Linear

PmA-Pewamo silty clay loam, 0\%-1\% slopes

Map Unit Setting

National map unit symbol: $2 \mathrm{t} 6 \mathrm{lv}$

Elevation: $700-1,300 \mathrm{ft}$

Mean annual precipitation: $32-42$ in

Mean annual air temperature: $48^{\circ} \mathrm{F}-54^{\circ} \mathrm{F}$

Frost-free period: $140-180 \mathrm{~d}$

Farmland classification: Prime farmland if drained

\section{Map Unit Composition}

Pewamo and similar soils: $85 \%$

Minor components: $15 \%$

Estimates are based on observations, descriptions, and transects of the map unit.

Description of Pewamo

Setting

Landform: Depressions on till plains, drainage ways on till plains

Landform position (two-dimensional): Toe slope

Landform position (three-dimensional): Base slope

Down-slope shape: Concave, linear

Across-slope shape: Concave

Parent material: Wisconsin till derived from limestone and shale

Typical profile

Ap- $0-11$ in: silty clay loam

Btg1-11-34 in: silty clay

Btg2 - 34-47 in: silty clay

$\mathrm{BCg}-47-57$ in: clay loam

Cg-57-79 in: clay loam

Properties and qualities

Slope: $0 \%-1 \%$

Depth to restrictive feature: More than 80 in

Natural drainage class: Very poorly drained

Runoff class: Negligible

Capacity of the most limiting layer to transmit water (Ksat): Moderately high $(0.20-0.60$

in/hr)

Depth to water table: About 0-12 in

Frequency of flooding: None

Frequency of ponding: Frequent

Calcium carbonate, maximum in profile: $30 \%$

Salinity, maximum in profile: Non-saline to very slightly saline $(0.0-2.0 \mathrm{mmhos} / \mathrm{cm})$

Available water storage in profile: Moderate (about 8.5 in)

Interpretive groups

Land capability classification (irrigated): None specified

Land capability classification (nonirrigated): $2 \mathrm{w}$

Hydrologic Soil Group: C/D

Hydric soil rating: Yes

Minor Components

Blount

Percent of map unit: 9\% 
Landform: End moraines on till plains, ground moraines on till plains

Landform position (two-dimensional): Footslope

Landform position (three-dimensional): Interfluve

Down-slope shape: Linear

Across-slope shape: Linear

Minster

Hydric soil rating: No

Percent of map unit: $6 \%$

Landform: Depressions on till plains

Landform position (two-dimensional): Toe slope

Landform position (three-dimensional): Base slope

Down-slope shape: Concave

Across-slope shape: Concave

Hydric soil rating: Yes

\section{Pt-Pits, quarry}

Map Unit Setting

National map unit symbol: pmlf

Mean annual precipitation: 34 to 42 inches

Mean annual air temperature: 48 to 55 degrees $\mathrm{F}$

Frost-free period: 140 to 180 days

Farmland classification: Not prime farmland

\section{Map Unit Composition}

Pits: 90 percent

Minor components: 10 percent

Estimates are based on observations, descriptions, and transects of the mapunit.

Description of Pits

Setting

Minor Components

Landform: End moraines, ground moraines

Udorthents, loamy

Percent of map unit: 8 percent

Hydric soil rating: No

Udorthents, clayey

Percent of map unit: 2 percent

Hydric soil rating: No

\section{Rs-Rossburg silt loam, occasionally flooded}

Map Unit Setting

National map unit symbol: $5 \mathrm{pg} 9$

Elevation: $500-700 \mathrm{ft}$

Mean annual precipitation: $27-42$ in

Mean annual air temperature: $45^{\circ} \mathrm{F}-55^{\circ} \mathrm{F}$

Frost-free period: $140-165 \mathrm{~d}$

Farmland classification: All areas are prime farmland

\section{Map Unit Composition}

Rossburg and similar soils: $90 \%$

Minor components: $10 \%$

Estimates are based on observations, descriptions, and transects of the map unit.

\section{Description of Rossburg}

Setting

Landform: Stream terraces, flood plains

Parent material: Alluvium

Typical profile 
H1-0-21 in: silt loam

H2-21-49 in: loam

H3-49-60 in: stratified gravelly sandy loam to silt loam

Properties and qualities

Slope: $0 \%-2 \%$

Depth to restrictive feature: More than 80 in

Natural drainage class: Well drained

Runoff class: Low

Capacity of the most limiting layer to transmit water (Ksat): Moderately high to high

$(0.60-2.00 \mathrm{in} / \mathrm{hr})$

Depth to water table: More than 80 in

Frequency of flooding: Occasional

Frequency of ponding: None

Calcium carbonate, maximum in profile: $30 \%$

Available water storage in profile: High (about 11.0 in)

Interpretive groups

Land capability classification (irrigated): None specified

Land capability classification (nonirrigated): $2 \mathrm{w}$

Hydrologic Soil Group: B

Ecological site: Moist Floodplain (F099XY008MI)

Hydric soil rating: No

Minor Components

Shoals

Percent of map unit: $4 \%$

Landform: Flood plains

Very poorly drained soils

Percent of map unit: $3 \%$

Landform: Abandoned channels on flood plains, abandoned channels on stream terraces

Hydric soil rating: Yes

Bedrock at $30-40$ in

Percent of map unit: $3 \%$

Sh-Shoals silt loam, $0 \%-2 \%$ slopes, frequently flooded

Map Unit Setting

National map unit symbol: 2t6lr

Elevation: $340-1,000 \mathrm{ft}$

Mean annual precipitation: $34-42$ in

Mean annual air temperature: $48^{\circ} \mathrm{F}-55^{\circ} \mathrm{F}$

Frost-free period: $140-180 \mathrm{~d}$

Farmland classification: Prime farmland if drained and either protected from flooding or not frequently flooded during the growing season

\section{Map Unit Composition}

Shoals and similar soils: $85 \%$

Minor components: $15 \%$

Estimates are based on observations, descriptions, and transects of the map unit.

Description of Shoals

Setting

Landform: Flood plains

Landform position (three-dimensional): Dip

Down-slope shape: Linear

Across-slope shape: Linear

Parent material: Loamy alluvium

Typical profile

Ap $-0-10$ in: silt loam

B-10-42 in: loam 
C - 42-79 in: stratified sandy loam to silt loam

Properties and qualities

Slope: $0 \%-2 \%$

Depth to restrictive feature: More than 80 in

Natural drainage class: Somewhat poorly drained

Runoff class: Low

Capacity of the most limiting layer to transmit water (Ksat): Moderately high to high

$(0.60-2.00 \mathrm{in} / \mathrm{hr})$

Depth to water table: About 6-18 in

Frequency of flooding: Frequent

Frequency of ponding: None

Calcium carbonate, maximum in profile: $22 \%$

Available water storage in profile: High (about 10.0 in)

Interpretive groups

Land capability classification (irrigated): None specified

Land capability classification (nonirrigated): $2 \mathrm{w}$

Hydrologic Soil Group: B/D

Minor Components

Hydric soil rating: No

Sloan

Percent of map unit: $8 \%$

Landform: Flood plains

Landform position (three-dimensional): Dip

Down-slope shape: Linear

Across-slope shape: Linear

Hydric soil rating: Yes

Eel

Percent of map unit: 7\%

Landform: Flood plains

Landform position (three-dimensional): Rise

Down-slope shape: Linear

Across-slope shape: Linear

Hydric soil rating: No

To-Toledo silty clay, $0 \%-1 \%$ slopes

Map Unit Setting

National map unit symbol: $2 \mathrm{v} 14 \mathrm{z}$

Elevation: $560-990 \mathrm{ft}$

Mean annual precipitation: $28-38$ in

Mean annual air temperature: $45^{\circ} \mathrm{F}-52^{\circ} \mathrm{F}$

Frost-free period: $135-210 \mathrm{~d}$

Farmland classification: Prime farmland if drained

Map Unit Composition

Toledo and similar soils: $90 \%$

Minor components: $10 \%$

Estimates are based on observations, descriptions, and transects of the map unit.

Description of Toledo

Setting

Landform: Lakebeds (relict)

Down-slope shape: Linear

Across-slope shape: Linear, concave

Parent material: Clayey glaciolacustrine deposits

Typical profile

Ap- $0-9$ in: silty clay

$\mathrm{Bg}-9-34$ in: silty clay 


\section{$-34-80$ in: silty clay \\ Properties and qualities}

Slope: $0 \%-1 \%$

Depth to restrictive feature: More than 80 in

Natural drainage class: Very poorly drained

Runoff class: Negligible

Capacity of the most limiting layer to transmit water (Ksat): Very low to low $(0.00-0.01$

in/hr)

Depth to water table: About $0-12$ in

Frequency of flooding: None

Frequency of ponding: Frequent

Calcium carbonate, maximum in profile: $21 \%$

Salinity, maximum in profile: Nonsaline $(0.0-0.6 \mathrm{mmhos} / \mathrm{cm})$

Available water storage in profile: Moderate (about 7.0 in)

Interpretive groups

Land capability classification (irrigated): None specified

Land capability classification (nonirrigated): $3 \mathrm{w}$

Hydrologic Soil Group: D

Ecological site: Wet Lake Plain Flats (F099XY013MI)

Hydric soil rating: Yes

Minor Components

Fulton

Percent of map unit: $6 \%$

Landform: Lakebeds (relict)

Microfeatures of landform position: Rises

Down-slope shape: Linear

Across-slope shape: Convex, linear

Hydric soil rating: No

Lenawee

Percent of map unit: $3 \%$

Landform: Lakebeds (relict)

Microfeatures of landform position: Open depressions

Down-slope shape: Linear

Across-slope shape: Concave, linear

Hydric soil rating: Yes

Haskins

Percent of map unit: $1 \%$

Landform: Lakebeds (relict)

Micro-features of landform position: Rises

Down-slope shape: Linear

Across-slope shape: Convex, linear

Hydric soil rating: No

\section{Tp-Toledo silty clay, $0 \%-1 \%$ slopes, flooded}

Map Unit Setting

National map unit symbol: 2v14y

Elevation: $560-620 \mathrm{ft}$

Mean annual precipitation: $28-38$ in

Mean annual air temperature: $45^{\circ} \mathrm{F}-52^{\circ} \mathrm{F}$

Frost-free period: $135-210 \mathrm{~d}$

Farmland classification: Not prime farmland

\section{Map Unit Composition}

Toledo, flooded, and similar soils: $95 \%$

Minor components: 5\%

Estimates are based on observations, descriptions, and transects of the map unit. 
Description of Toledo, Flooded

Setting

Landform: Terraces

Landform position (three-dimensional): Tread

Down-slope shape: Linear

Across-slope shape: Linear, concave

Parent material: Clayey glaciolacustrine deposits

Typical profile

Ap $-0-8$ in: silty clay

$\mathrm{Bg}-8-34$ in: silty clay

$\mathrm{Cg}-34-80$ in: silty clay

Properties and qualities

Slope: 0\%-1\%

Depth to restrictive feature: More than 80 in

Natural drainage class: Very poorly drained

Runoff class: Negligible

Capacity of the most limiting layer to transmit water (Ksat): Very low to low (0.00-0.01

in/hr)

Depth to water table: About 0-12 in

Frequency of flooding: Frequent

Frequency of ponding: Frequent

Calcium carbonate, maximum in profile: $20 \%$

Salinity, maximum in profile: Nonsaline $(0.0-0.6 \mathrm{mmhos} / \mathrm{cm})$

Available water storage in profile: Moderate (about 6.8 in)

Interpretive groups

Land capability classification (irrigated): None specified

Land capability classification (nonirrigated): $4 \mathrm{w}$

Hydrologic Soil Group: D

Ecological site: Wet Floodplain (F099XY009MI)

Minor Components

Hydric soil rating: Yes

Fulton, flooded

Percent of map unit: 5\%

Landform: Terraces

Landform position (three-dimensional): Tread

Microfeatures of landform position: Rises

Down-slope shape: Linear

Across-slope shape: Convex, linear

Hydric soil rating: Yes

\section{TpA-Toledo silty clay, $0 \%-1 \%$ slopes, flooded}

\section{Map Unit Setting}

National map unit symbol: $2 \mathrm{v} 14 \mathrm{y}$

Elevation: $560-620 \mathrm{ft}$

Mean annual precipitation: $28-38$ in

Mean annual air temperature: $45^{\circ} \mathrm{F}-52^{\circ} \mathrm{F}$

Frost-free period: $135-210 \mathrm{~d}$

Farmland classification: Not prime farmland

\section{Map Unit Composition}

Toledo, flooded, and similar soils: $95 \%$

Minor components: 5\%

Estimates are based on observations, descriptions, and transects of the map unit.

Description of Toledo, Flooded

Setting

Landform: Terraces 
Landform position (three-dimensional): Tread

Down-slope shape: Linear

Across-slope shape: Linear, concave

Parent material: Clayey glaciolacustrine deposits

Typical profile

Ap- $0-8$ in: silty clay

$\mathrm{Bg}-8-34$ in: silty clay

Cg-34-80 in: silty clay

Properties and qualities

Slope: $0 \%-1 \%$

Depth to restrictive feature: More than 80 in

Natural drainage class: Very poorly drained

Runoff class: Negligible

Capacity of the most limiting layer to transmit water (Ksat): Very low to low $(0.00-0.01$

in/hr)

Depth to water table: About 0-12 in

Frequency of flooding: Frequent

Frequency of ponding: Frequent

Calcium carbonate, maximum in profile: $20 \%$

Salinity, maximum in profile: Nonsaline $(0.0-0.6 \mathrm{mmhos} / \mathrm{cm})$

Available water storage in profile: Moderate (about 6.8 in)

Interpretive groups

Land capability classification (irrigated): None specified

Land capability classification (nonirrigated): $4 \mathrm{w}$

Hydrologic Soil Group: D

Ecological site: Wet Floodplain (F099XY009MI)

Minor Components

Hydric soil rating: Yes

Fulton, flooded

Percent of map unit: 5\%

Landform: Terraces

Landform position (three-dimensional): Tread

Microfeatures of landform position: Rises

Down-slope shape: Linear

Across-slope shape: Linear, convex

Hydric soil rating: Yes

\section{$\underline{\text { W-Water }}$}




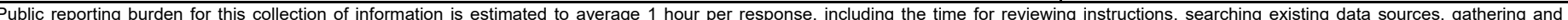

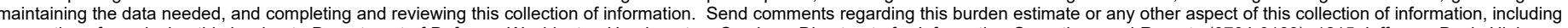

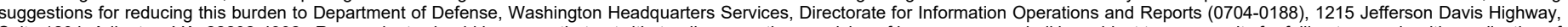

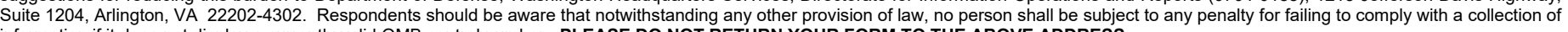
information if it does not display a currently valid OMB control number. PLEASE DO NOT RETURN YOUR FORM TO THE ABOVE ADDRESS.

\section{REPORT DATE (DD-MM-YYYY) \\ 2. REPORT TYPE \\ September 2021 \\ Final Technical Report \\ 4. TITLE AND SUBTITLE}

3. DATES COVERED (From - To)

An Evaluation of Soil Phosphorus Storage Capacity (SPSC) at Proposed Wetland

Restoration Locations in the Western Lake Erie Basin

5a. CONTRACT NUMBER

5b. GRANT NUMBER

5c. PROGRAM ELEMENT NUMBER

6. AUTHOR(S)

5d. PROJECT NUMBER

478112-U4375451

Jacob F. Berkowitz, Christine M. VanZomeren, Nia R. Hurst

and Kristina J. Sebastian

5e. TASK NUMBER

5f. WORK UNIT NUMBER

7. PERFORMING ORGANIZATION NAME(S) AND ADDRESS(ES)

U.S. Army Engineer Research and Development Center

Environmental Laboratory

3909 Halls Ferry Road

NUMBER

Vicksburg, MS 39180

ERDC/EL TR-21-6

9. SPONSORING / MONITORING AGENCY NAME(S) AND ADDRESS(ES)

USACE Buffalo District

LRB

1776 Niagara Street

Buffalo, NY 14207

11. SPONSOR/MONITOR'S REPORT NUMBER(S)

12. DISTRIBUTION / AVAILABILITY STATEMENT

Approved for public release; distribution is unlimited.

\section{SUPPLEMENTARY NOTES}

Funding provided by MIPR W81EU602896379.

\section{ABSTRACT}

Historical loss of wetlands coupled with excess phosphorus (P) loading at watershed scales have degraded water quality in portions of the western Lake Erie Basin (WLEB). In response, efforts are underway to restore wetlands and decrease P loading to surface waters. Because wetlands have a finite capacity to retain P, researchers have developed techniques to determine whether wetlands function as P sources or sinks. The following technical report evaluates the soil P storage capacity (SPSC) at locations under consideration for wetland restoration in collaboration with the Great Lakes Restoration Initiative (GLRI) and the H2Ohio initiative. Results indicate that the examined soils display a range of P retention capacities, reflecting historic land-use patterns and management regimes. However, the majority of study locations exhibited some capacity to se-quester additional P. The analysis supports development of rankings and comparative analyses of areas within a specific land parcel, informing management through design, avoidance, removal, or remediation of potential legacy P sources. Additionally, the approaches described herein support relative comparisons between multiple potential wetland development properties. These results, in conjunction with other data sources, can be used to target, prioritize, justify, and improve decision-making for wetland management activities in the WLEB.

\section{SUBJECT TERMS}

Wetland restoration

Erie, Lake

Soils-Phosphorus content Environmental management

\section{a. REPORT}

Unclassified

\section{b. ABSTRACT}

Unclassified c. THIS PAGE

Unclassified

Soils-Sampling

17. LIMITATION OF ABSTRACT

SAR
18. NUMBER OF PAGES

68 19a. NAME OF RESPONSIBLE PERSON

19b. TELEPHONE NUMBER (include area code) 